\title{
Thermal Release of Volatile Fission Products from Irradiated Nuclear Fuel
}
L. A. Bray
L. L. Burger
L. G. Morgan
D. L. Baldwin

June 1983

Prepared for the U.S. Department of Energy under Contract DE-AC06-76RLO 1830

Pacific Northwest Laboratory Operated for the U.S. Department of Energy by Battelle Memorial Institute 


\title{
DISCLAIMER
}

This report was prepared as an account of work sponsored by an agency of the United States Government. Neither the United States Government nor any agency thereof, nor any of their employees, makes any warranty, express or implied, or assumes any legal liability or responsibility for the accuracy, completeness, or usefulness of any information, apparatus, product, or process disclosed, or represents that its use would not infringe privately owned rights. Reference herein to any specific commercial product, process, or service by trade name, trademark, manufacturer, or otherwise, does not necessarily constitute or imply its endorsement, recommendation, or favoring by the United States Government or any agency thereof. The views and opinions of authors expressed herein do not necessarily state or reflect those of the United States Government or any agency thereof.

\author{
PACIFIC NORTHWEST LABORATORY \\ operated by \\ BATTELLE \\ for the \\ UNITED STATES DEPARTMENT OF ENERGY \\ under Contract DE-AC06-76RLO 1830
}

\begin{tabular}{|c|c|}
\hline \multicolumn{2}{|c|}{$\begin{array}{l}\text { National Technical Information Service } \\
\text { United States Department of Commerce } \\
\text { 5285 Pont Royal Road } \\
\text { Springfield, Virginia } 22161\end{array}$} \\
\hline \multicolumn{2}{|c|}{$\begin{array}{l}\text { NTIS Price Codes } \\
\text { Microfiche A0T }\end{array}$} \\
\hline \multicolumn{2}{|c|}{ Printed Copy } \\
\hline Pages: & $\begin{array}{l}\text { Price } \\
\text { Codes }\end{array}$ \\
\hline $001-025$ & $\mathrm{~A} 02$ \\
\hline $026-050$ & $\mathrm{~A} 03$ \\
\hline $051-075$ & $A 04$ \\
\hline $076-100$ & A05 \\
\hline $101-125$ & $A 06$ \\
\hline $126-150$ & $A 07$ \\
\hline $151-175$ & $A 08$ \\
\hline $176-200$ & $A 09$ \\
\hline $201-225$ & $A 010$ \\
\hline 226.250 & $A 011$ \\
\hline $251-275$ & $A 012$ \\
\hline $276-300$ & A013 \\
\hline
\end{tabular}




\section{2}

PNL -4488

UC-70

THERMAL RELEASE OF VOLATILE FISSION

PRODUCTS FROM IRRADIATED NUCLEAR FUEL
L. A. Bray
L. L. Burger
L. G. Morgan
D. L. Baldwin (a)

June 1983

Prepared for

the U.S. Department of Energy

under Contract DE-AC06-76RLO 1830

Pacific Northwest Laboratory

Richland, Washington 99352

(a) Hanford Engineering Development Laboratory, Richland, Washington. 

The Pacific Northwest Laboratory (PNL) has conducted a study to evaluate thermal release of volatile fission products from irradiated nuclear fuel. An effective procedure for removing tritium, xenon and krypton from irradiated fuels was demonstrated using Shippingport $\mathrm{UO}_{2}$ fuel. The release characteristics of tritium, krypton, xenon, and iodine from irradiated nuclear fuel have been determined as a function of temperature and gaseous environment. Vacuum outgassing and a flowing gas stream have been used to -vary the gaseous environment. Vacuum outgassing released approximately $99 \%$ of the tritium and $20 \%$ of both krypton and xenon within 3 hours at a temperature of $1500^{\circ} \mathrm{C}$. Similar results were obtained using a carrier gas of helium (He) containing $6 \%$ hydrogen $\left(\mathrm{H}_{2}\right)$. However, a carrier gas containing only He resulted in the release of approximately $80 \%$ of the tritium and $99 \%$ of both $\mathrm{Kr}$ and $\mathrm{Xe}$. These results indicate that the release of these volatile fission products from irradiated nuclear fuel is a function of the chemical composition of the gaseous environment.

Tritium release using a flowing gas stream was studied from $1100^{\circ} \mathrm{C}$ to $1500^{\circ} \mathrm{C}$. The rate of tritium release increased with increasing temperature and with the addition of hydrogen to the gas stream. Using crushed $\mathrm{UO}_{2}$ fuel without cladding and $\mathrm{He}$ as the carrier gas, $\mathrm{Kr}$ was completely released at $1500^{\circ} \mathrm{C}$ in 2.5 hours. Below $1350^{\circ} \mathrm{C}$, no $\mathrm{Kr}$-Xe release was observed. Approximately $86 \%$ of the ${ }^{129} \mathrm{I}$ and $95 \%$ of the cesium was released from a piece $(3.9 \mathrm{~g})$ of $\mathrm{UO}_{2}$ fuel at $1500^{\circ} \mathrm{C}$ in $\mathrm{He}$. The zirconium cladding was observed to fracture during heat treatment.

A large scale thermal outgassing system was conceptually designed by the General Atomic Company (now G. A. Technologies) from an engineering analysis of available experimental data. The direct cost of a 0.5 metric/ton day thermal outgassing system is estimated to be $\$ 1,926,000$ (1982 dollars), including equipment, installation, instrumentation and controls, piping, and services. The thermal outgassing process was determined to be a technically feasible and 
cost-competitive process to remove tritium in the head-end portion of a light water reactor (LWR) fuel reprocessing plant. Additional laboratory-scale development has been recommended. 


\section{CONTENTS}

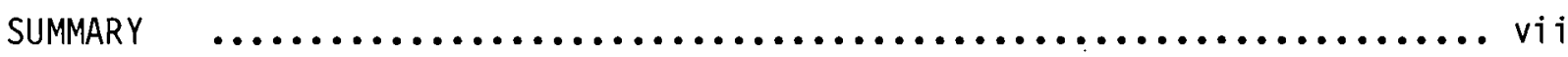

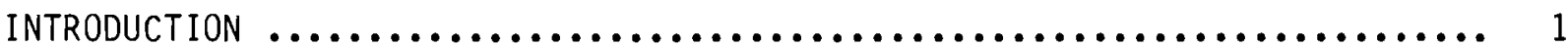

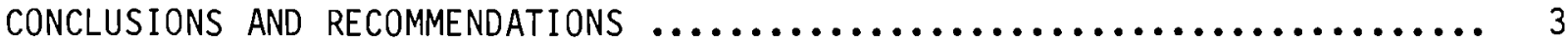

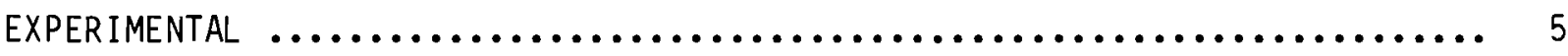

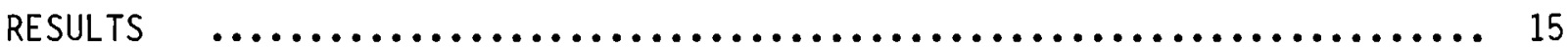

THERMAL VACUUM OUTGASSING $\ldots \ldots \ldots \ldots \ldots \ldots \ldots \ldots \ldots \ldots \ldots \ldots \ldots \ldots$

THERMAL SWEEP-GAS OUTGASSING $\ldots \ldots \ldots \ldots \ldots \ldots \ldots \ldots \ldots \ldots \ldots \ldots \ldots \ldots$

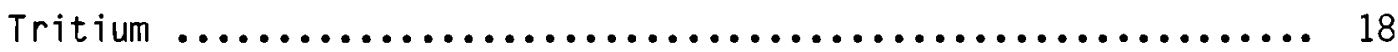

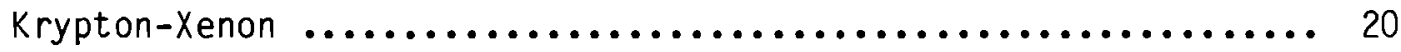

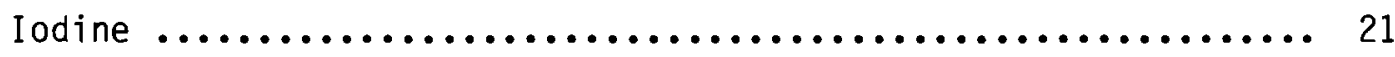

Analysis of $\mathrm{UO}_{2}$ Fuel and Residual Dissolver Solids .......... 23

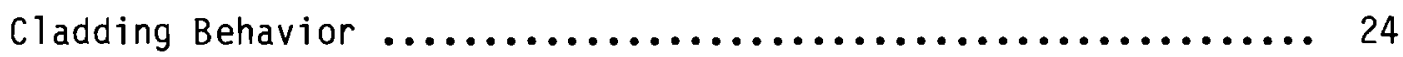

Engineering Evaluation $\ldots \ldots \ldots \ldots \ldots \ldots \ldots \ldots \ldots \ldots \ldots \ldots \ldots$

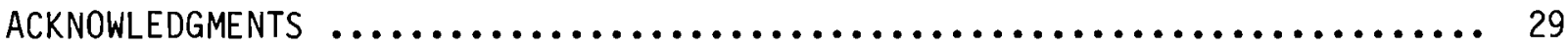

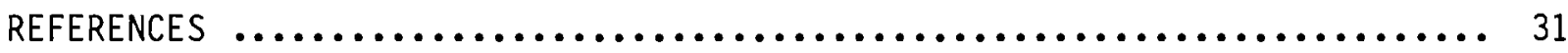

APPENDIX A - SUMMARY OF THERMAL SWEEP-GAS RESULTS $\ldots \ldots \ldots \ldots \ldots \ldots \ldots \ldots \ldots .1$

APPENDIX B - THERMAL OUTGASSING ENGINEERING STUDY $\ldots \ldots \ldots \ldots \ldots \ldots \ldots \ldots \ldots$ 


\section{FIGURES}

1 Plan View of the In-Cell Experimental Vacuum Outgassing System ...... 6

2 Schematic Layout of the In-Cell Gas Handling, Pressure Monitoring System Used in the Vacuum Outgassing Fission Gas Release Studies ..... 7

3 Schematic of the Thermal Sweep-Gas Equipment $\ldots \ldots \ldots \ldots \ldots \ldots \ldots \ldots$

4 Shippingport PWR Core-1, $\mathrm{UO}_{2}$ Fuel $\operatorname{Rod} \ldots \ldots \ldots \ldots \ldots \ldots \ldots \ldots \ldots \ldots$

5 Shippingport Fuel Pin Sample Cutting Diagram $\ldots \ldots \ldots \ldots \ldots \ldots \ldots \ldots \ldots$

$6 \mathrm{a}$ View of the Vacuum Outgassing Furnace with Two $1 / 2 \mathrm{in}$. Zircaloy-2

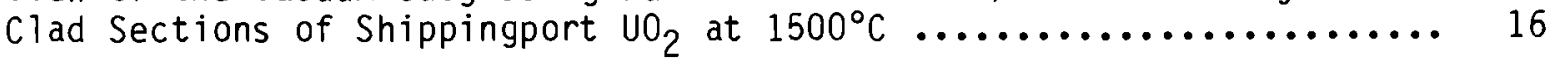

6b View of the Vacuum Outgassing Furnace with $8.69 \mathrm{~g}$ of Crushed Shippingport $\mathrm{UO}_{2}$ at $1575^{\circ} \mathrm{C}$

7 Cross Section of Shippingport $\mathrm{UO}_{2}$ Fuel Before and After Thermal Vacuum Outgassing

8 Krypton and Xenon Release as a Function of Time Using Thermal vacuum Outgassing

9 Tritium Release as a Function of Time and Temperature with Pure He as Sweep Gas ................................... 22

10 Tritium Release as a Function of Time and Temperature with $6 \% \mathrm{H}_{2}+\mathrm{He}$ Sweep Gas

11 Krypton Release as a Function of Temperature, Time, and

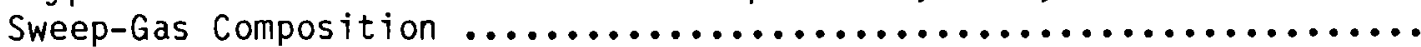

12 Shippingport $\mathrm{UO}_{2} \mathrm{Clad}$ Fuel Section After Heating in Helium at $1500^{\circ} \mathrm{C}$ 
1 Description of Shippingport $\mathrm{UO}_{2}$ Reactor Fuel Element $\ldots \ldots \ldots \ldots \ldots \ldots$

2 Shippingport $v 0_{2}$ Fuel Standards Analysis $\ldots \ldots \ldots \ldots \ldots \ldots \ldots \ldots \ldots \ldots$

3 Shippingport $\mathrm{UO}_{2}$ Fuel Fission Gas Analysis of Pin as

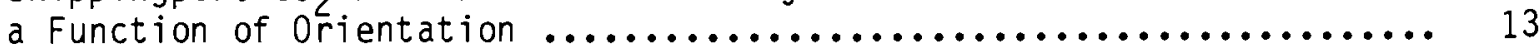

4 Residual Values for Tests $\mathrm{BNW}-01$ and $\mathrm{BNW}-02$ after Thermal Vacuum Outgassing ..................................... 19

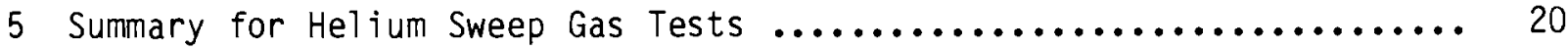

6 Summary for $6 \%$ Hydrogen + Helium Sweep Gas Tests ................ 21

7 Analysis of $\mathrm{UO}_{2}$ Fuel Dissolver Solution and Filtered Solids as a Function of Thermal Outgassing Treatment 1 


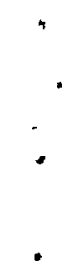


INTRODUCTION

The release of fission products from irradiated nuclear fuel as a function of temperature and chemical environment is an important consideration for inreactor behavior, e.g. thermal transients or accidents, for interim or longterm storage of irradiated fuel and for head-end steps in reprocessing.

For reprocessing, the removal of these gaseous fission products, particularly tritium and iodine-129, before the dissolution step simplifies their recovery for isolation. Voloxidation, found to be only partially effective for noble gas and iodine removal, does remove tritium. However, the equipment required and the needed control of the exothermic reaction resulting from the oxidation of $\mathrm{UO}_{2}$ to $\mathrm{U}_{3} \mathrm{O}_{8}$ are significant problems. Another limitation is its inability to be used with thoria fuels. Removal of tritium, iodine, and noble gases by thermal treatment in the absence of oxygen is an attractive alternative.

For pretreatment of unreprocessed spent fuel for long-term storage, the removal of volatile nuclides which have above average mobility in the environment will.provide improved long-term safety. In addition, data on chemical species, on thermally induced migration, and on fuel stability will lead to a better understanding of the migration mechanisms in fuel elements during both normal and accident conditions.

Accurate data on the release of fission products from irradiated nuclear fuel as a result of reactor transients or accident situations, as a function of the thermal conditions and composition of the atmosphere in contact with the fuel, must be available in order to analyze the consequences of the accident. However, experimentally determined fission product releases as a function of the accident conditions do not exist in sufficient quantity to allow these needed analyses. Likewise, computer modeling of nuclear reactor accidents is severely hampered by lack of quantitative data on fission product releases. Most of the data used in these models is either speculative or based on very limited and inadequate experimental data. 
The inadequacy of the source terms used for release of volatile fission products was illustrated by the Three Mile Island No. 2 incident. Prior to this accident, it was widely assumed that essentially all of the fission product iodine would be released as elemental iodine in a nuclear reactor accident. In fact, very little elemental iodine was released beyond the containment building of TMI-2. Potential reasons for the absence of the release of significant quantities of elemental iodine have been given (Campbell et al. 1981). However, these speculations are not supported by definitive experimental results, a fact that was recognized and stated by the authors of the article.

Many theoretical and experimental studies concerning the release of fission products from fuel have been published (Morgan et al. 1983). Most have dealt with migration within the fuel capsule. A lesser number have been concerned with release of volatiles on heating, and a few studies have examined the water (steam) reactions. In spite of the large amount of work done, the release of the volatile and semivolatile fission products is not well characterized.

On behalf of the above concerns, thermal outgassing studies were initiated at PNL in FY 1979 through the Airborne Waste Management Program Office, Idaho Falls, Idaho, and was terminated at the end of FY 1982 prior to completion of the outlined test program. During the period, substantive hot-cell equipment was made operational. Analytical equipment was developed to determine various nuclides in-line as well as to do residual analyses on both the sweep gas and the heated fuel.

This report describes the experimental approaches used for the thermal studies, the analytical methods, and the results obtained under different conditions of heating and exposure to sweep gases. Engineering and economic evaluation of the thermal outgassing process is included as an appendix. 
CONCLUSIONS AND RECOMMENDATIONS

Thermal release of fission gases from irradiated nuclear fuels was achieved with the use of a sweep gas. Vacuum outgassing was partially successful, but besides being more effective, the sweep-gas technique was easier to employ. The following items were demonstrated:

- Complete release of krypton from the fuel and complete release of tritium from both the fuel and cladding can be obtained with the high temperature sweep-gas process. The heat treatment does not significantly affect the dissolution properties of the fuel in nitric acid.

- The addition of $6 \% \mathrm{H}_{2}$ to the He sweep-gas results in greatly improved tritium release as a function of time but hinders the krypton release. The dramatic effect of the presence of $\mathrm{H}_{2}$ in the He sweep-gas shows that the composition of the atmosphere around the heated fuel is very important to fission gas and semivolatile release. Observations, such as the appearance of iodine as $I_{2}$, suggest that experiments using traces of other gases such as $\mathrm{O}_{2}$ in the sweep gas would be instructive. Other inert gases such as Ar and $\mathrm{N}_{2}$ need to be studied.

- Most of the iodine and cesium are released when an inert gas is used. When $6 \% \mathrm{H}_{2}$ is present, the cesium remains in the fuel. Additional data are required to explain the behavior of iodine, cesium, and other semivolatile fission products.

- Under some conditions, the cladding is fractured in the heat treatment; thus chopping the fuel may not be necessary. Further investigation of cladding fracturing and interaction with $\mathrm{UO}_{2}$ could lead to an alternative head-end process. 
- An engineering evaluation of the process as a head-end step for fuel reprocessing shows that thermal sweep-gas outgassing is technically feasible and cost competitive. A conceptual pilot-plant test system to be used to verify design assumptions and identify potential scale-up problems is described. 


\section{EXPER IMENTAL}

Two experimental approaches were used in this study. The first employed vacuum outgassing as the fuel was rapidly heated. This experiment utilized an extensively instrumented system installed in a shielded cell and included; a resistance heated vacuum furnace, an in-line quadrupole mass spectrometer, a video camera and recorder using $x$-ray transmission, an optical pyrometer, and additional gas sampling bulbs (Hinman and Slagle 1978). The gas samples were available for subsequent examination by gas chromatography (GC) and high resolution mass spectroscopy (MS). The equipment is shown in Figures 1 and 2 .

The second approach utilized a carrier gas to remove volatiles as the fuel elements were heated. The released fission products were identified, and quantities determined by a combination of real-time analyses and samples collected over specified time periods. Figure 3 is a schematic of the sweep-gas release apparatus, which consists of a gas purification system, a Lindberg (Model No. 54233) high-temperature tube furnace with a 2-in. ID by 30-in. long mullite tube, various traps, counting equipment, and a GC. Krypton-85 is monitored with the use of an in-line gamma spectrometer. In addition, xenon may be cryogenically trapped and measured using a SKG, Inc., component concentrator, Model 215; an F and M Scientific, Model 700, gas chromatograph, and a spectrophysics integrator. Iodine is trapped on charcoal immediately upon exiting the furnace and the $1-129$ measured by $x$-ray spectroscopy. The tritium $\left({ }^{3} H\right)$ and carbon $\left({ }^{14} \mathrm{C}\right)$ samples were counted using a Nuclear Chicago Mark 1, Model 6860 liquid scintillation counter.

In some experiments, it took up to 3 hours to raise the temperature to the final value. The push rod shown in the diagram permits an isothermal alternative to the temperature ramp experiment, $i . e$. , the sample may be inserted when the furnace is at final temperature.

To analyze the fission gas content in the fuel before testing or the residual gas remaining in the fuel samples after thermal outgassing, a fission gas analyzer, model XK-10, designed by D. L. Baldwin and manufactured by Leco Corporation, was used. This analyzer rapidly melted the fuel to release all of 


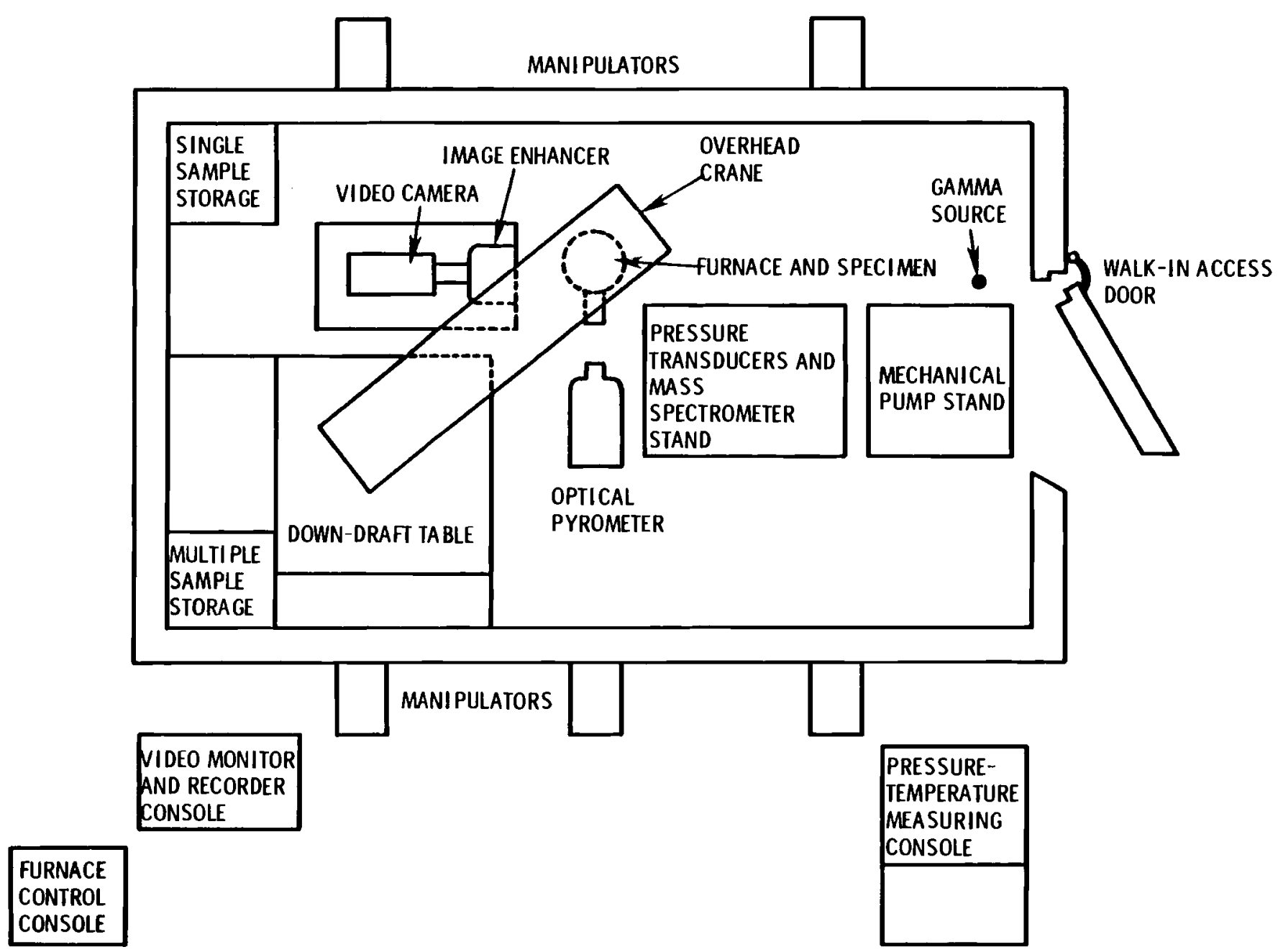

FIGURE 1. Plan View of the In-Cell Experimental Vacuum Outgassing System (from Hinman and Slagle 1978) 


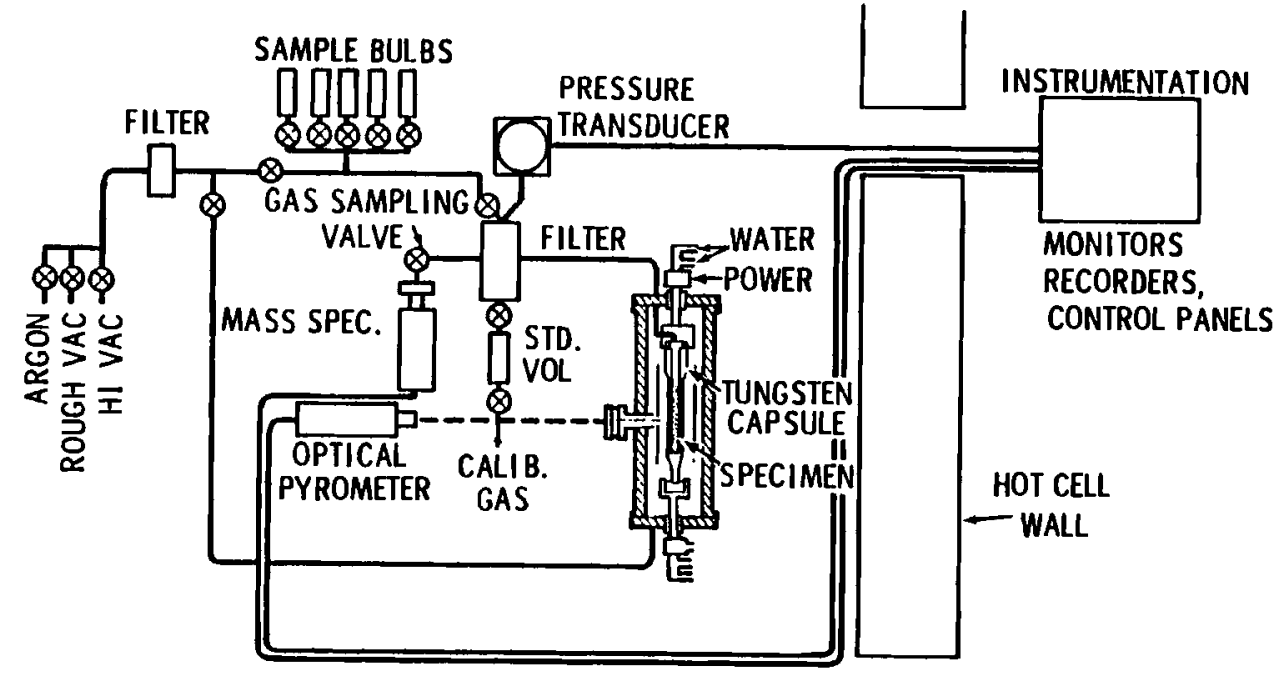

FIGURE 2. Schematic Layout of the In-Cell Gas Handling, Pressure Monitoring System Used in the Vacuum Outgassing Fisson Gas Release Studies (from Hinman and Slagle 1978)

the gas and analyzed the sample for total xenon and krypton. The ${ }^{3} H$ and ${ }^{14} \mathrm{C}$ are then passed through a $600^{\circ} \mathrm{C}$ tube furnace containing copper oxide to convert the ${ }^{3} \mathrm{H}$ to water vapor and the ${ }^{14} \mathrm{C}$ to ${ }^{14} \mathrm{CO}_{2}$. The gas stream is then passed through a water solution to trap the ${ }^{3} \mathrm{H}$ and through caustic solution to trap ${ }^{14} \mathrm{C}$.

The irradiated fuel experiments were carried out with pins from a 47-rod section of a Shippingport PWR core 2, seed 4 blanket fuel. A description of the fuel is given in Table 1 and Figure 4. Segments of the $\mathrm{UO}_{2}$ and $\mathrm{cladding}$ were obtained by cutting the cladding. Fuel samples varied during the test program from $1 / 2-i n$. clad sections to powdered fuel. The analysis of the initial fuel used during the tests is shown in Table 2. In addition, a fuel pin was sectioned to determine the fission gas content along the rod (Figure 5). The results in Table 3 show that the tritium is divided equally between the cladding and $\mathrm{UO}_{2}$, and that $17 \%$ of the tritium is in the cladding per unit length of fuel. No fission gas was found in the cladding void space when the fuel pin was penetrated by a laser prior to sectioning. 
THERMAL OUTGASSING OF UO FUEL ANALYSIS OF $X_{\theta}, 86 \mathrm{Kr}, 1291$, $3 \mathrm{H}$ AND $14 \mathrm{C}$

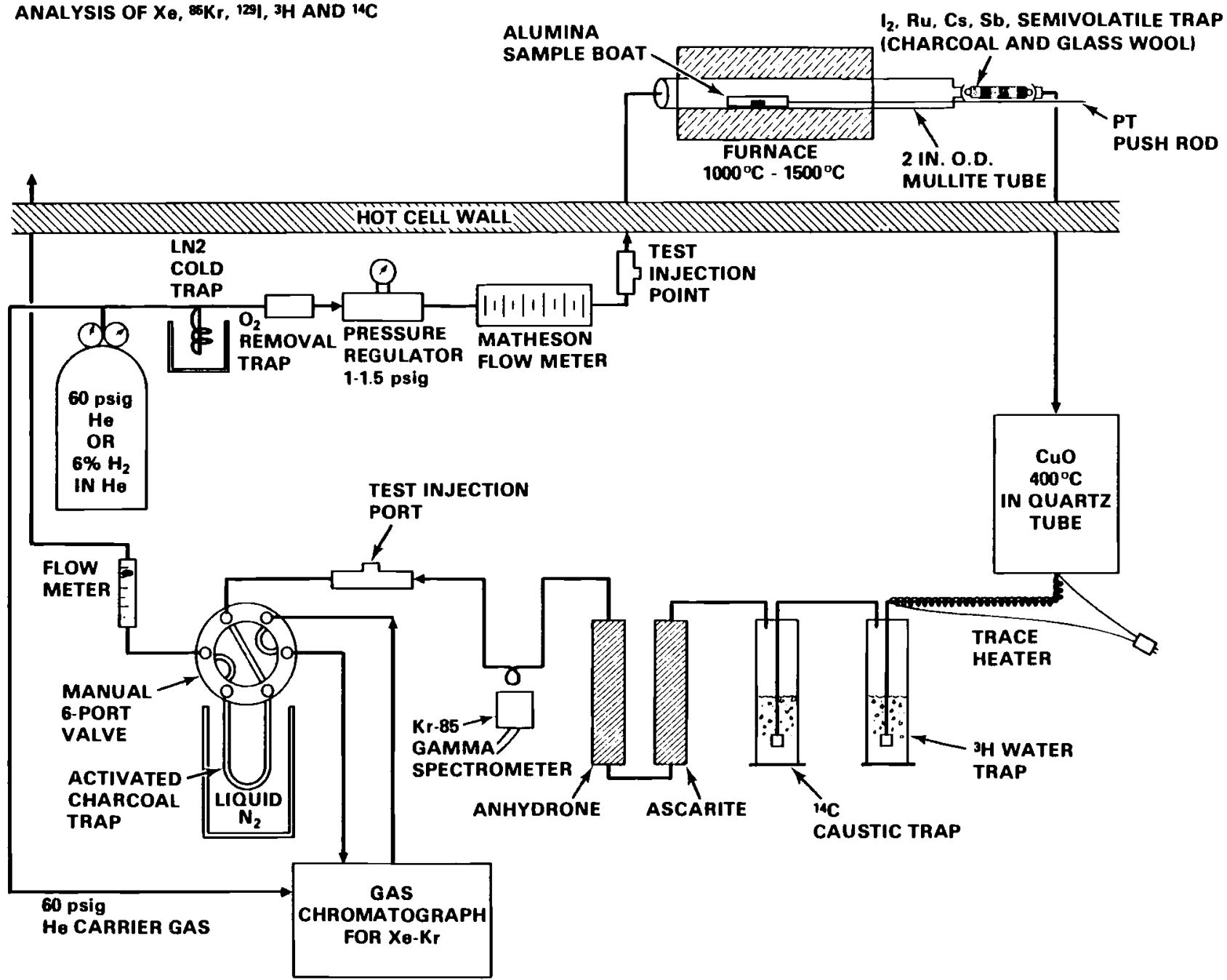

FIGURE 3. Schematic of Thermal Sweep-Gas Equipment 
TABLE 1. Description of Shippingport $\mathrm{UO}_{2}$ Reactor Fuel El ement

Source:

Shippingport - PWR Core 1, Blanket, after four seed lives operated between $12 / 2 / 57$ and $2 / 9 / 64$ with periodic shutdowns. Final shutdown was $2 / 9 / 64$.

Pin Size:

Approximately 0.4 in. dia $\times 20.25$ in. long, Zircaloy-2 clad

Fuel Content:

Uranium - $0.13 \mathrm{~kg}$

Plutonium - $0.68 \mathrm{~g}$

Hours Operating: approximately 47,280

Burnup :

$5.9 \times 10^{20}$ fissions/cc average

23,709 MWd/MTU average

$8.44 \times 1020$ fissions/CC peak

33,916 MWd/MTU peak 

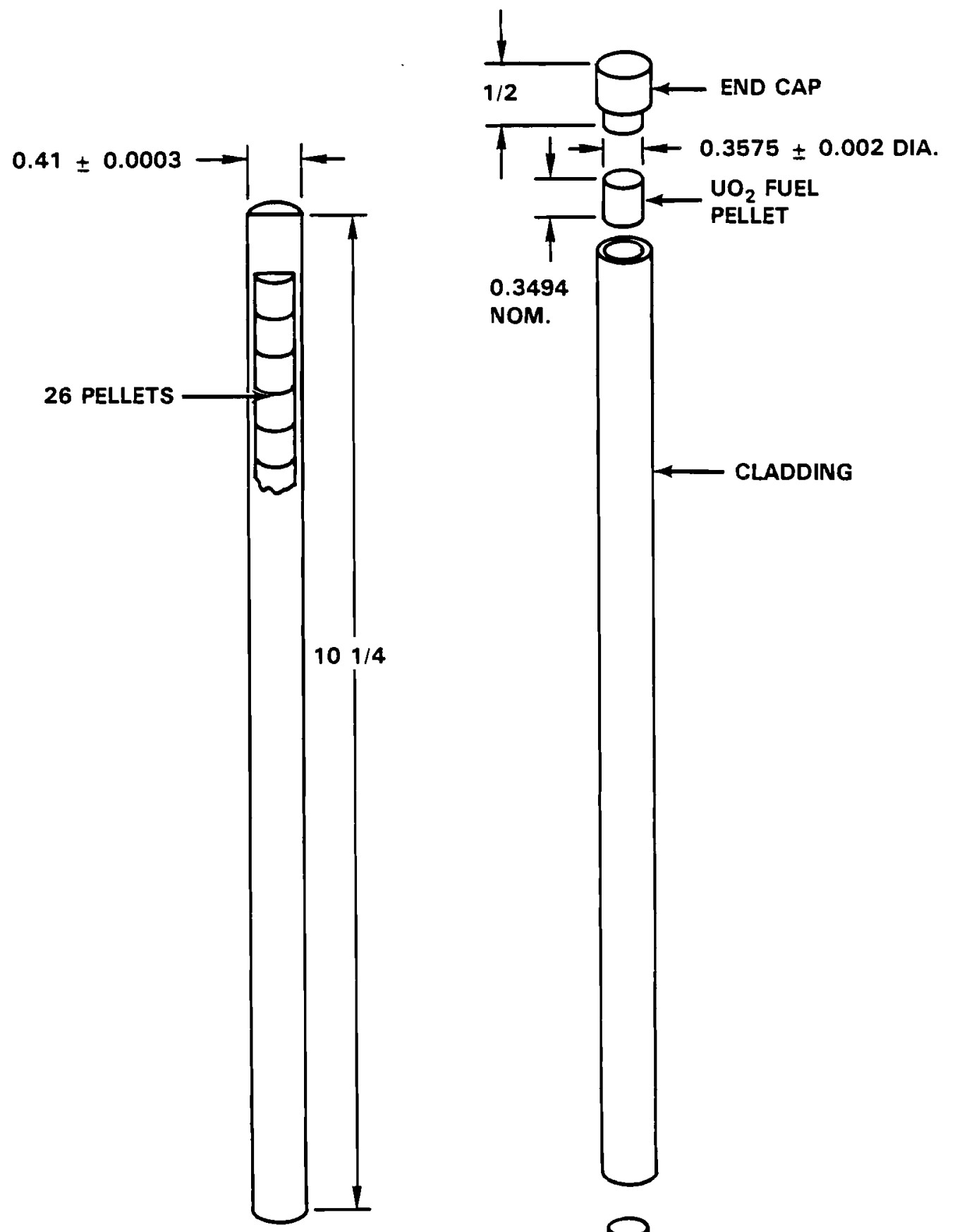

NOM.

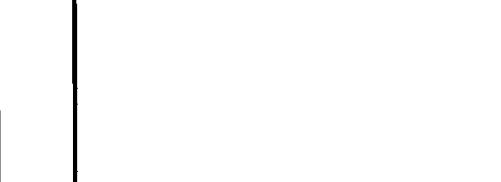

CLADDING

DIMENSIONS ARE INCHES

FIGURE 4. Shippingport PWR Core-1, $\mathrm{UO}_{2}$ Fuel Rod 


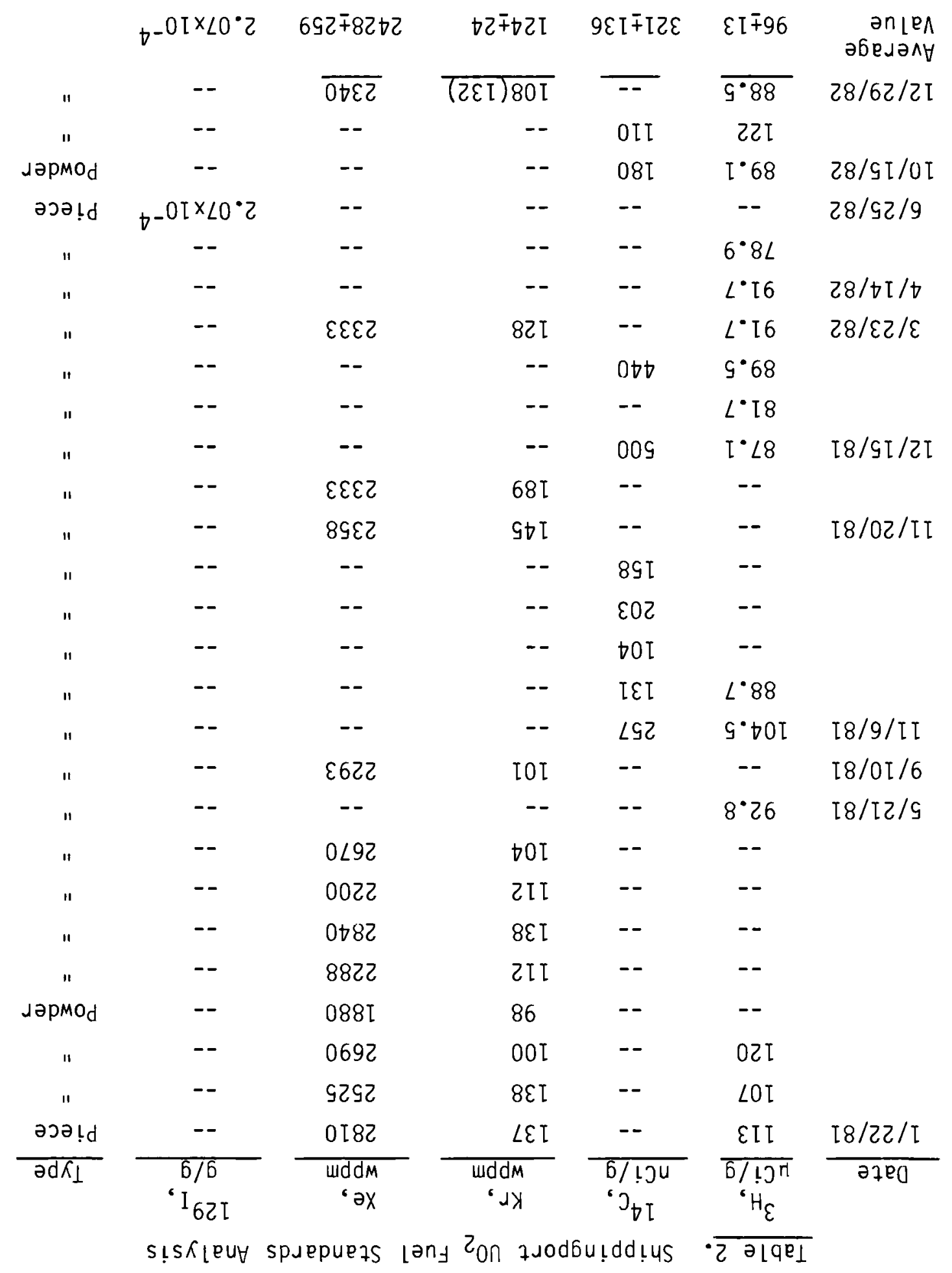




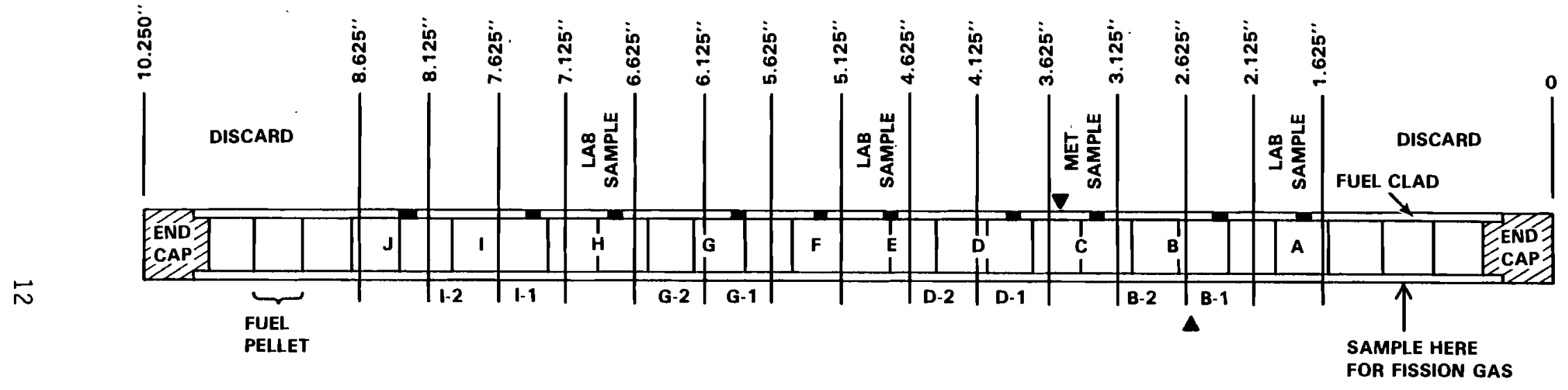

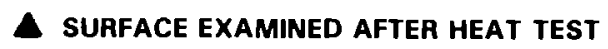

$\checkmark$ SURFACE EXAMINED BEFORE HEAT TEST

- $0^{\circ}$ ORIENTATION MARK

FIGURE 5. Shippingport Fuel Pin Sample Cutting Diagram 
TABLE 3. Shippingport $\mathrm{UO}_{2}$ Fuel Fission Gas Analysis of Pin as a Function of Orientation

\begin{tabular}{|c|c|c|c|c|c|c|c|c|}
\hline $\begin{array}{c}\text { Orientation, } \\
\text { in. }\end{array}$ & Sample & $\frac{{ }^{3} \mathrm{H}, \mu}{\text { Fue I }}$ & $\frac{/ g(a)}{\text { Clad }}$ & $\begin{array}{c}{ }^{14} \mathrm{C}, \mathrm{nCi} / \mathrm{g} \\
\text { Fuel } \\
\end{array}$ & $\begin{array}{l}85_{\mathrm{Kr}} \\
\text { FueT }\end{array}$ & $\frac{\text { wppm }}{\text { Clad }}$ & Xe, & $\begin{array}{l}\text { wppm } \\
\text { CTad }\end{array}$ \\
\hline $2.125-1.625$ & A & 63.2 & 69.7 & 212 & 134 & -- & 3187 & -- \\
\hline $5.125-4.625$ & $E$ & 73.2 & 78.3 & 167 & 102 & 0 & 2317 & -- \\
\hline $7.125-6.625$ & $H$ & 83.2 & 81.5 & 302 & 122 & 0 & 3053 & -- \\
\hline
\end{tabular}

(a) $3.45 \mathrm{~g}$ of clad and $18 \mathrm{~g}$ of $\mathrm{UO}_{2}$ per in. (length). 


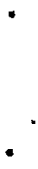




\section{RESULTS}

The results of the tests on thermal vacuum outgassing and thermal sweepgas outgassing are presented below and in Appendix $A$.

THERMAL VACUUM OUTGASSING

The first of two vacuum outgassing tests (BNW-01) was completed after months of installing and testing equipment and its extensive instrumentation. Only 10 to $15 \%$ of the fission gas was removed from the two $1 / 2-i n$. sections $(B-1, B-2)$ of zirconium-clad Shippingport $U 0_{2}$ fuel. The fuel was heated under vacuum at $200^{\circ} \mathrm{C} / \mathrm{s}$ and held at $1500^{\circ} \mathrm{C}$ for 2 hours. Then the vacuum was lost when the fuel contained in a molybdenum foil touched the surface walls causing a pinhole leak. The test was terminated at this point, rather than at 6 hours, as was planned previously. This early termination and the loss of three gas samples due to a defective o-ring meant that BNW-01 served mainly to test the equipment.

Valuable data gathered during BNW-01 included the temperature of the heated system, its total pressure, the partial pressures of selected gaseous components, a view (Figure $6 \mathrm{~A}$ ) of the fuel using gamma radiography and photomicrographs taken before and after heating (Figure 7). Interaction between the cladding and fuel was evident from the photomicrographs and may be caused by the loss of vacuum.

The second test (BNW-02) involved sections $G-1$ and $G-2$ (Figure 6B), in which the $\mathrm{UO}_{2}$ fuel was separated from the cladding. The crushed fuel pellets $(8.69 \mathrm{~g})$ were placed in an $\mathrm{Al}_{2} \mathrm{O}_{3}$ crucible with a molybdenum $1 \mathrm{id}$, heated at $200^{\circ} \mathrm{C} / \mathrm{s}$, and held at $1575^{\circ} \mathrm{C}$ for 3 hours. Total pressure and partial pressures were again monitored with pressure transducers and a mass spectrometer during the anneal. Five gas samples taken during the run were analyzed for tritium, xenon, and krypton content. The in-line spectrometer and the first gas sample showed that all of the tritium was released during the first 5 minutes of heating. Krypton and xenon were found in the first four gas samples. The release of $\mathrm{Kr}$ and $\mathrm{Xe}$ are shown in Figure 8 as a function of time. Based on mass 


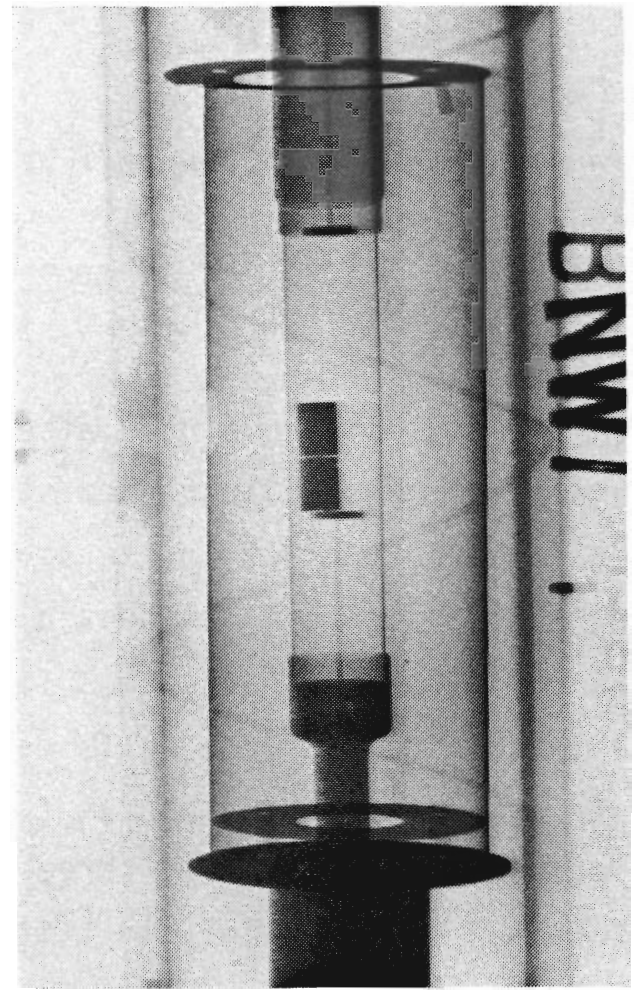

FIGURE 6A. View of the Vacuum Outgassing Furnace with Two 1/2-in. Zircaloy-2 Clad Sections $(B-1, B-2)$ of Shippingport $\mathrm{UO}_{2}$ at $1500^{\circ} \mathrm{C}$

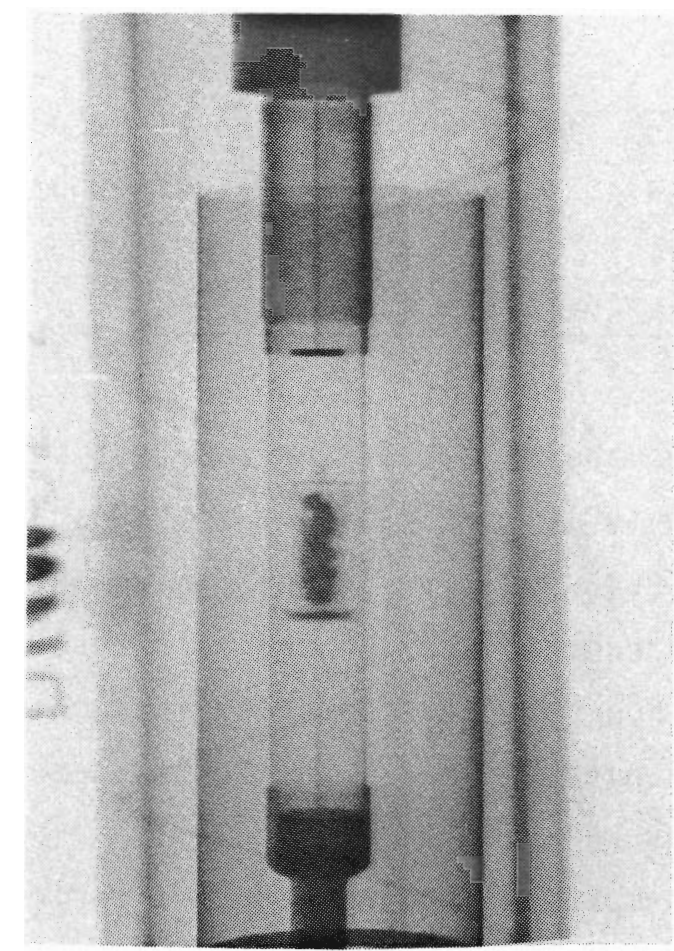

FIGURE 6B. View of Vacuum Outgassing Furnace with $8.69 \mathrm{~g}$ of Crushed Shippingport $\mathrm{UO}_{2}(\mathrm{G}-1$ and $\mathrm{G}-2)$ at $1575^{\circ} \mathrm{C}$

spectrometer results and average composition (Table 2), approximately $20 \%$ of the $\mathrm{Xe}$ and $24 \%$ of the $\mathrm{Kr}$ were released during the 3 -hour test. These results compare favorably with test BNW-01, in which $15 \%$ of the $\mathrm{Xe}$ and $36 \%$ of the $\mathrm{Kr}$ were released from the two Zircaloy-2 clad sections.

Residual values for ${ }^{3} \mathrm{H}$, Xe, and $\mathrm{Kr}$, determined for tests $\mathrm{BNW}-01(\mathrm{~B}-1)$ and BNW-02 (G-1, G-2) are shown in Table 4. The results for BNW-01 indicated that $99 \%{ }^{3} \mathrm{H}, 61 \% \mathrm{Xe}$, and $42 \% \mathrm{Kr}$ were released from the fuel. (The mass spectrometer results had indicated a release of $15 \% \mathrm{Xe}$ and $36 \% \mathrm{Kr}$ as compared to known standards.) Only $5 \%$ of the ${ }^{3} \mathrm{H}$ initially in the Zircaloy-2 cladding remained. The results for BNW-02 compare favorably with the mass spectrometer results, showing that $97.4 \%{ }^{3} \mathrm{H}, 19 \% \mathrm{Xe}$, and $26 \% \mathrm{Kr}$ had been released. 


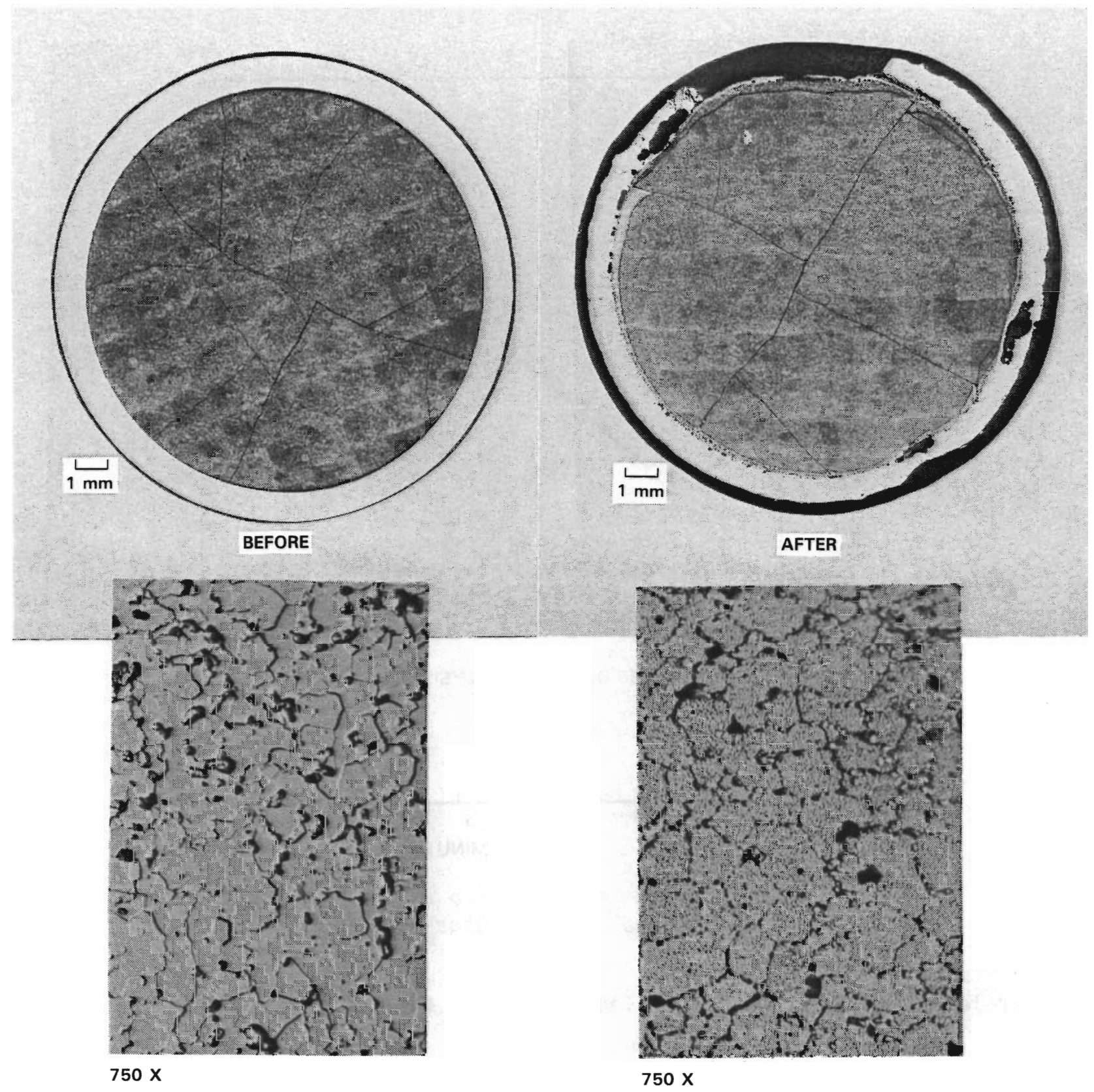

FIGURE 7. Cross Section of Shippingport $\mathrm{UO}_{2}$ Fuel Before and After Thermal Vacuum Outgassing

THERMAL SWEEP-GAS OUTGASSING

Typical results are listed in Tables 5 and 6 , and results for tritium, krypton, and xenon are graphically presented in Figures 9 and 10. Linear portions of the percent release vs. (time) ${ }^{1 / 2}$ plot suggest that at least part of 


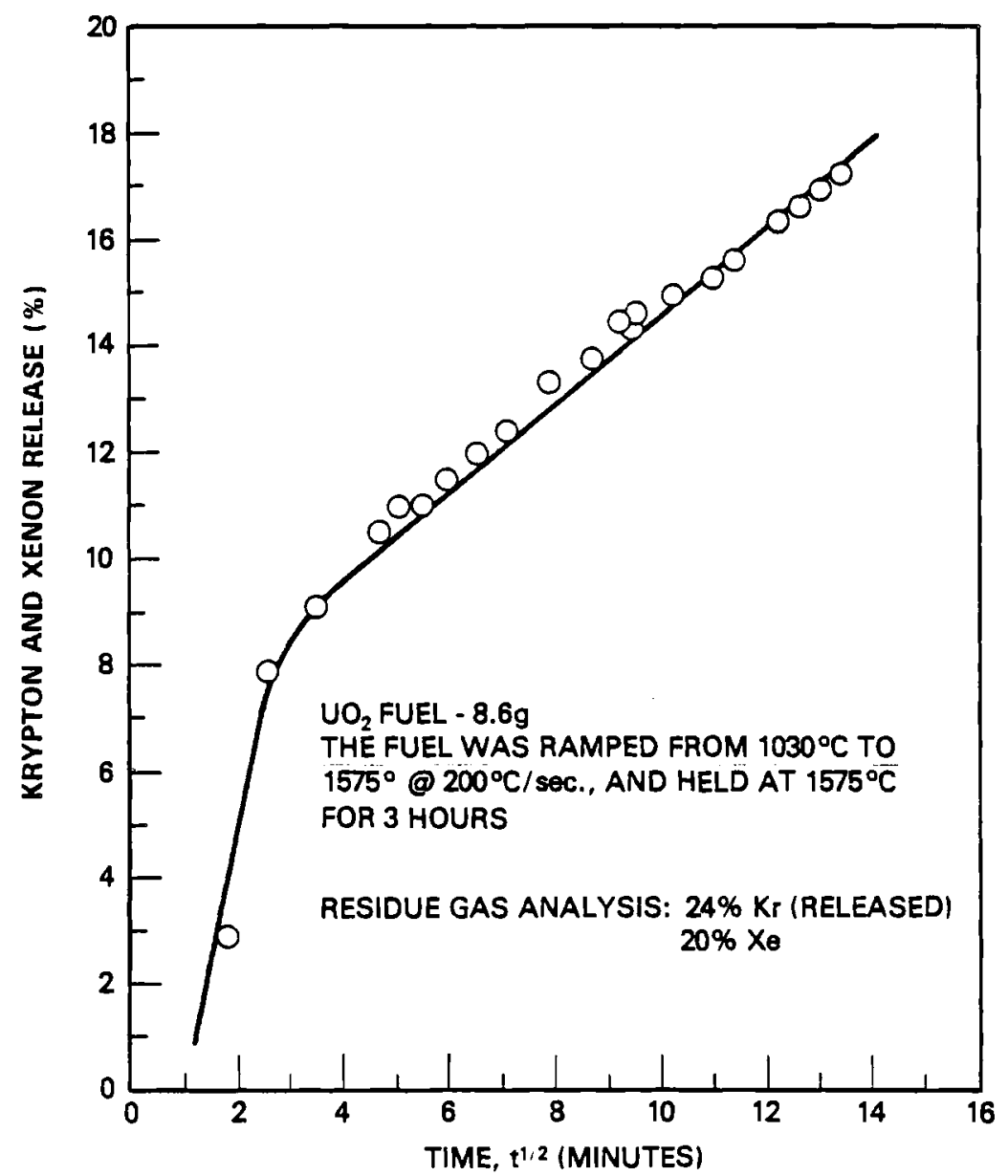

FIGURE 8. Krypton and Xenon Release as a Function of Time Using Thermal Vacuum Outgassing

the release is diffusion controlled. However, the temperature dependence suggests a threshold effect for some of the releases.

Most of the tests were isothermal. They produced basically the same results as the temperature ramp experiments, although the isothermal release time was 3 to 4 hours less.

\section{Tritium}

With pure helium as the sweep gas, temperature is the most significant variable. Figure 9 shows that only $8 \%$ of the tritium was released at $650^{\circ} \mathrm{C}$ and about $14 \%$ at $1100^{\circ} \mathrm{C}$. At $1300^{\circ} \mathrm{C}$ or above, the release was much faster and much 
TABLE 4. Residual Values for Tests BNW-01 and BNW-02 After Thermal Vacuum Outgassing

\begin{tabular}{|c|c|c|c|c|}
\hline & $\begin{array}{r}3 \mathrm{H} \\
\mu \mathrm{Ci} / \mathrm{g} \\
\end{array}$ & $\begin{array}{l}{ }^{14} \mathrm{C} \\
\mathrm{nCi} / \mathrm{g}\end{array}$ & $\begin{array}{l}\text { Xe, } \\
\text { wppm }\end{array}$ & $\begin{array}{l}\mathrm{Kr}, \\
\text { wppm }\end{array}$ \\
\hline \multicolumn{5}{|l|}{$\begin{array}{l}\text { Test: BNW-01 } \\
\text { Sample: B-1 }\end{array}$} \\
\hline Assumed initial value(a) & $68(72)^{(b)}$ & 200 & 2850 & 120 \\
\hline Results & 0.3 & 90 & 1470 & 89 \\
\hline & & & 884 & {$[399](c)$} \\
\hline & & & 1480 & 53 \\
\hline & $(3.3)$ & & 661 & 85 \\
\hline & & & & 89 \\
\hline & & & & 33 \\
\hline Average residual & $0.3(3.3)$ & 90 & 1124 & 70 \\
\hline$\%$ Outgassed & $99+$ & 55 & 61 & 42 \\
\hline & $(95)$ & & & \\
\hline \multicolumn{5}{|l|}{$\begin{array}{l}\text { Test: } B N W-02 \\
\text { Sample: G-1, G-2 }\end{array}$} \\
\hline Assumed initial value $(a)$ & 81 & 215 & 2700 & 115 \\
\hline Results & 2.1 & & 2316 & 86 \\
\hline & & & 2079 & 80 \\
\hline & & & & 90 \\
\hline Average residual & 2.1 & -- & 2198 & 85 \\
\hline$\%$ Outgassed & 97.4 & -- & 19 & 26 \\
\hline
\end{tabular}

(a) Based on Table 3 .

(b) $\mathrm{Clad}=($ ).

(c) Not used $=[]$.

more complete. There is considerable scatter in the tritium release data when helium only is used as a carrier.

When $6 \%$ hydrogen was added to the helium, the data were more consistent. There was an appreciable increase in release rate in the vicinity of $1000^{\circ} \mathrm{C}$. At the higher temperatures, the hydrogen effect is less certain. The release 
TABLE 5. Summary for Helium Sweep Gas Tests

Remaining in Fue 1

\begin{tabular}{|c|c|c|c|c|c|c|}
\hline Material & Temp, ${ }^{\circ} \mathrm{C}$ & $\begin{array}{c}\text { Time, } \\
\mathrm{h}\end{array}$ & $\begin{array}{r}\text { After } \\
\text { Tritium }\end{array}$ & $\begin{array}{l}\text { Thermal } \\
\text { Krypton }\end{array}$ & $\frac{\text { Outgassi }}{\text { Xenon }}$ & $\frac{g, \%}{\text { Iodine }}$ \\
\hline \multicolumn{7}{|l|}{$\mathrm{UO}_{2}$ Powder } \\
\hline & $35-1500$ & 6 & 22 & 0.7 & 0.6 & -- \\
\hline & 1500 & 1 & 0.7 & 8 & 8 & -- \\
\hline & $"$ & 2 & 0.6 & 8 & 8 & -- \\
\hline & $"$ & 2 & 0.7 & 8 & 4.0 & -- \\
\hline & $"$ & 2 & 3.8 & 8 & 10 & -- \\
\hline & $"$ & 2.5 & 1 & 1 & 0.9 & -- \\
\hline & 1400 & 3 & 1.8 & 20 & 16 & -- \\
\hline & 1350 & 3 & 1.2 & 37 & 31 & -- \\
\hline & 1350 & 5 & 2.1 & 12 & 18 & -- \\
\hline & 1300 & 3 & 1.5 & 100 & 100 & -- \\
\hline & 1300 & 12 & 2.5 & 19 & 26 & -- \\
\hline & 1250 & 4 & 4.2 & 100 & 100 & -- \\
\hline & 1100 & 4 & 88 & 100 & 100 & -- \\
\hline & 650 & 12 & 81 & $52 ?$ & 100 & -- \\
\hline
\end{tabular}

$\mathrm{UO}_{2}$ Pieces

$$
\begin{aligned}
& 35-1500 \\
& 1500
\end{aligned}
$$

1" Zirc Clad

Fuel Section

$\begin{array}{rrrrr}6 & 19 & 5 & 10 & -- \\ 12 & 0.5 & 3 & 4 & 14\end{array}$

of tritium from powdered fuel approaches 100\% in 1 to 2 hours heating time in either pure $\mathrm{He}$ or $\mathrm{He}+6 \% \mathrm{H}_{2}$. Typical data from powdered fuel are shown in Figure 10.

Krypton-Xenon

Data for krypton and xenon showed less scatter than that for tritium. Data for krypton at different temperatures are shown in Figure 11. With helium as the sweep gas, greater than 95\% of the krypton was removed in 2 hours at 
TABLE 6. Summary for $6 \%$ Hydrogen + Helium Sweep Gas Tests

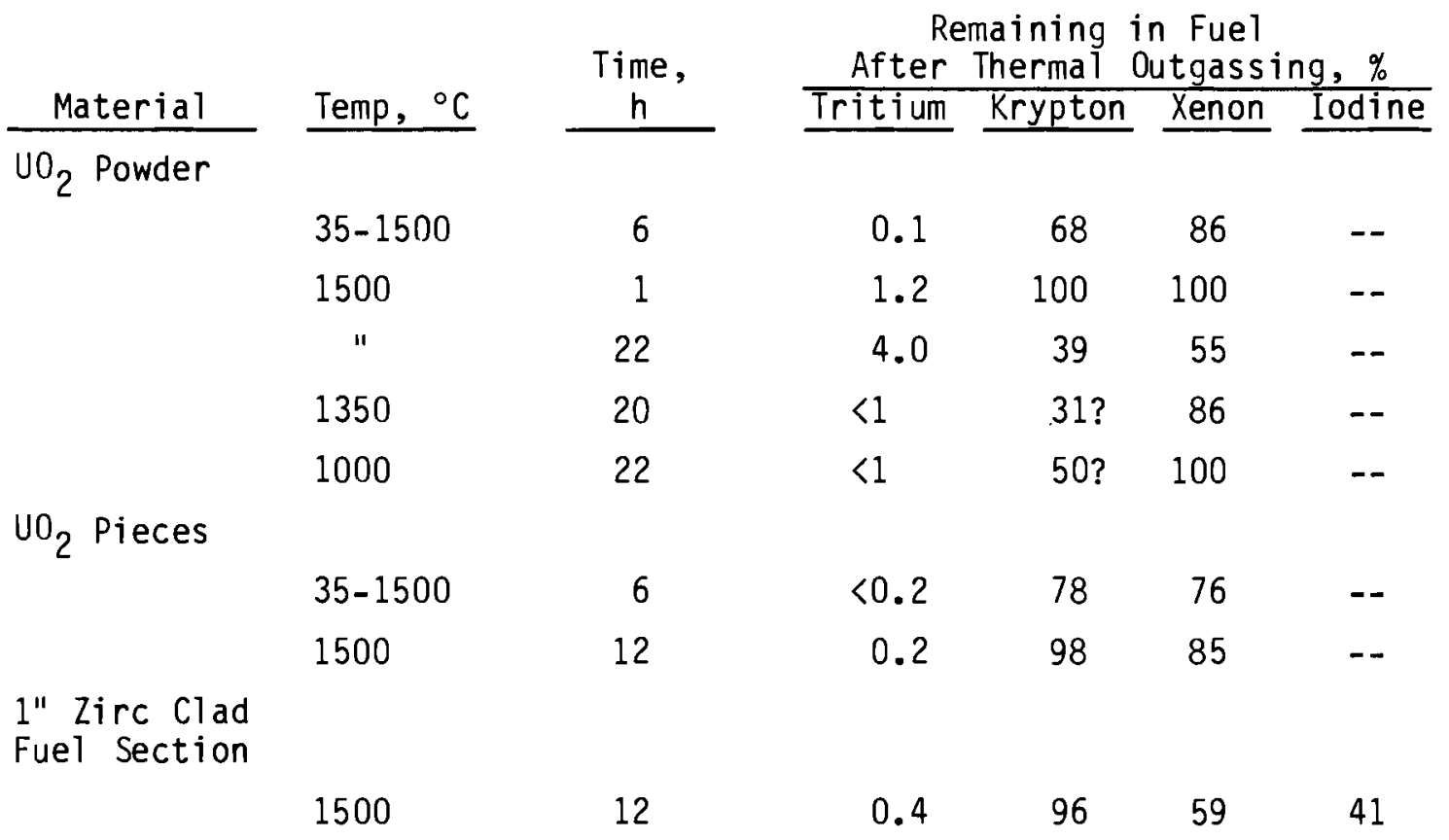

$1500^{\circ} \mathrm{C}$. Xenon behaves similarly. The most notable effect with the noble gases was the large decrease in release rate if hydrogen was present. The releases with pure helium in 1 hour were greater than $90 \%$ for both $\mathrm{Kr}$ and $\mathrm{Xe}$. With $6 \%$ $\mathrm{H}_{2}$ present, releases after 1 hour were $40 \%$ for $\mathrm{Kr}$ and about $25 \%$ for $\mathrm{Xe}$. Iodine

Attempts were made to determine the pathway for iodine. Iodine was trapped on charcoal as it exited the furnace and was measured by $x$-ray spectroscopy. The trap consisted of several charcoal sections separated by glass wool dividers. Iodine was found only in the first section. The measurements indicate that at $1500^{\circ} \mathrm{C}$, using a sweep gas of $\mathrm{He}, 15 \%$ of the fission product iodine was released. Some ${ }^{125} \mathrm{Sb},{ }^{106} \mathrm{Ru},{ }^{137} \mathrm{Cs},{ }^{144} \mathrm{Ce}$, and ${ }^{154} \mathrm{Eu}$ were found on the initial glass wool ahead of the charcoal section, but only ${ }^{125}$ Sb was found with the ${ }^{129} \mathrm{I}$ on the charcoal. When the thermally treated $\mathrm{UO}_{2}$ was dissolved and analyzed, only $14 \%$ of the initial iodine $\left(207 \mathrm{~g}^{129} \mathrm{I} /\right.$ tonne) had remained in the fuel after outgassing. Therefore, $71 \%$ of the iodine was unaccounted for in the experiment. In addition, only $5 \%$ of the ${ }^{134-137}$ Cs remained in the fuel after 


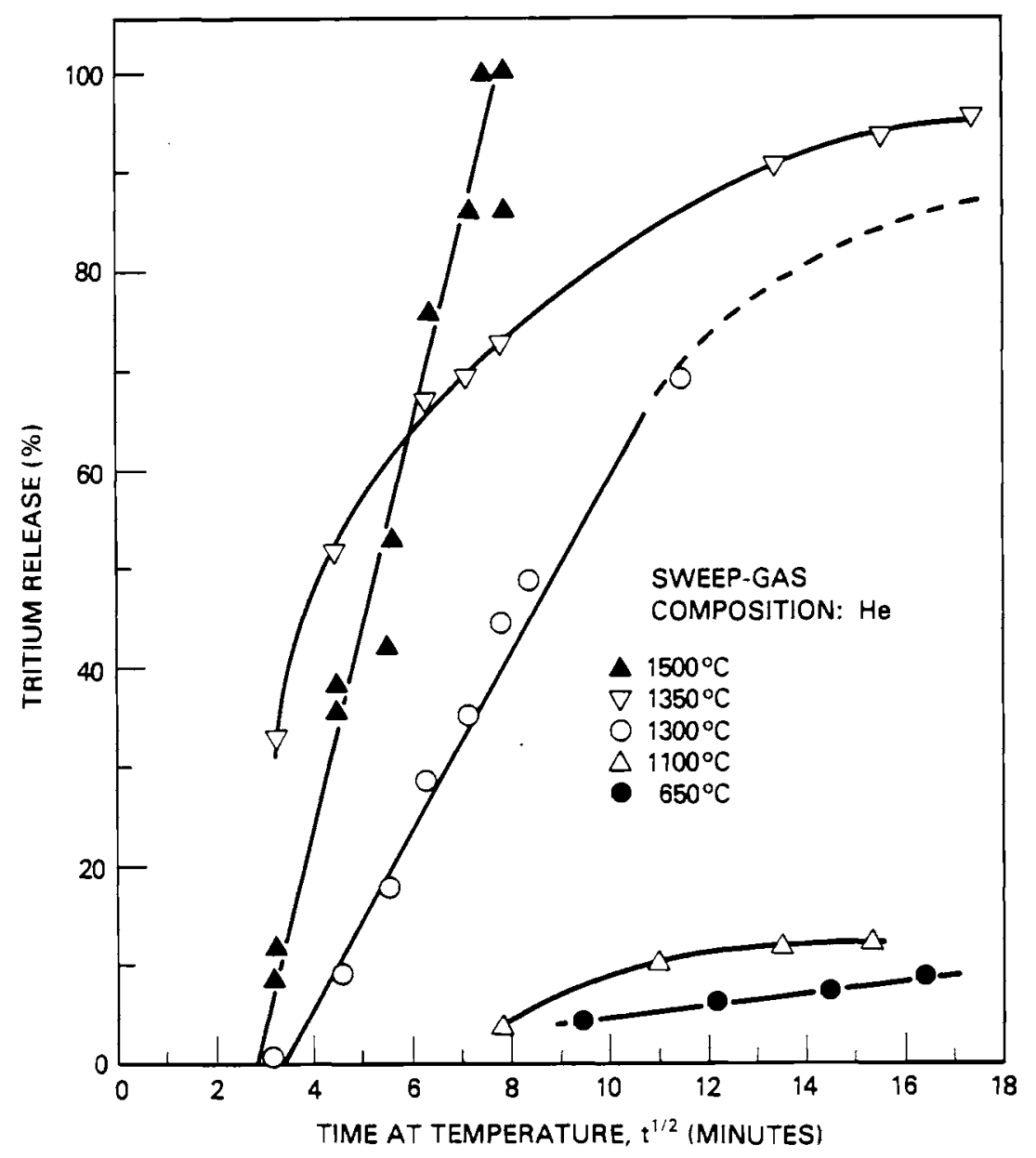

FIGURE 9. Tritium Release as a Function of Time and Temperature with Pure He as Sweep Gas

after heating to $1500^{\circ} \mathrm{C}$ in He (Table 7). When fuel was treated at $1500^{\circ} \mathrm{C}$ using a sweep-gas of $6 \% \mathrm{H}_{2}+\mathrm{He}$, only $41 \%$ of the iodine was found in the final dissolved fuel, and the cesium remained in the fuel.

It was expected that cesium and iodine would appear in combined form, deposited on the walls of the furnace tube. However, some iodine was found free of cesium in the first charcoal section. There are several possible explanations for this. Cesium iodide will react with $\mathrm{UO}_{2}$ in the presence of traces of oxygen to produce cesium uranate and iodine. This has been demonstrated in our laboratory. Thus, it is possible that $\mathrm{I}_{2}$ was released as such. 


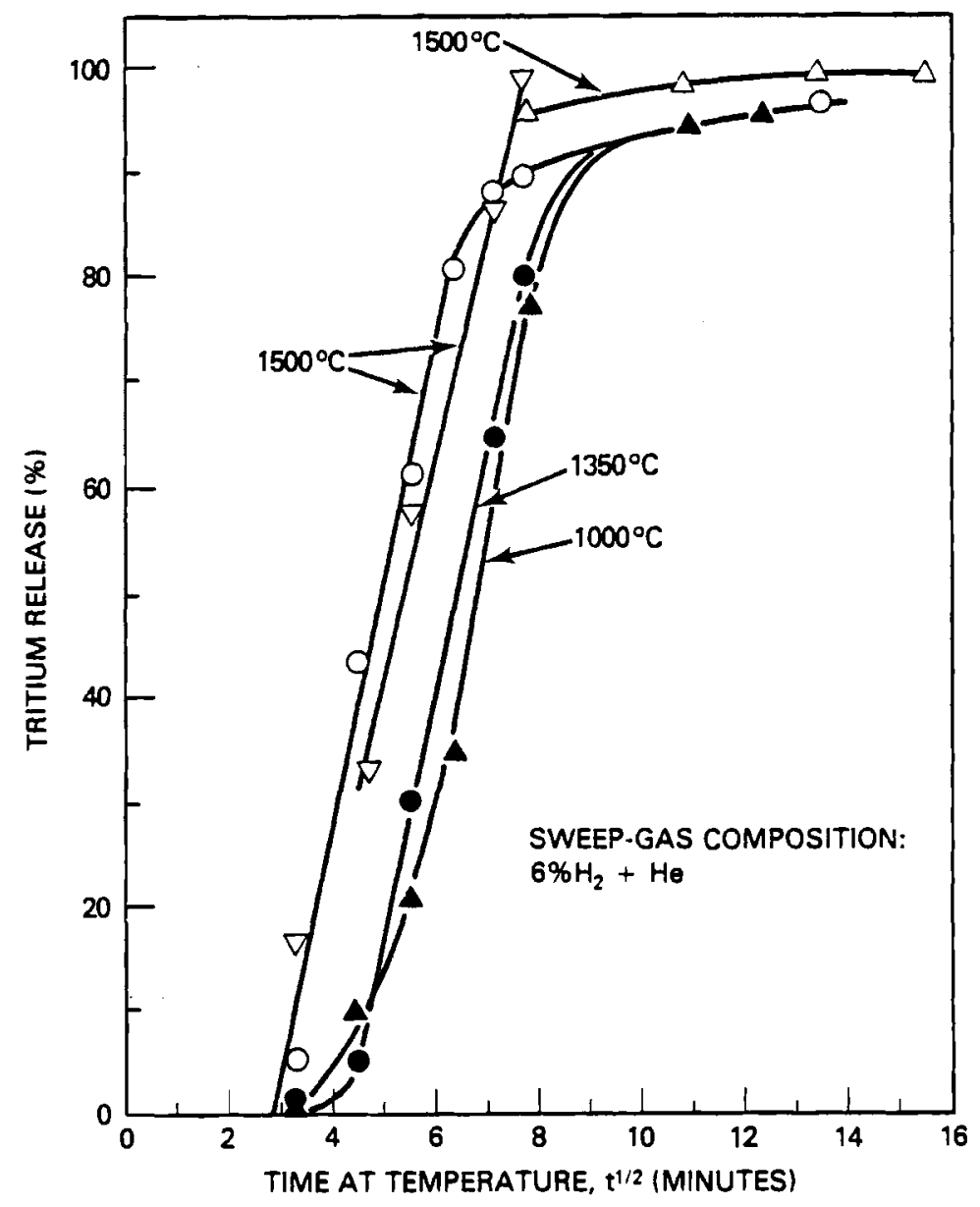

FIGURE 10. Tritium Release as a Function of Time and Temperature with $6 \% \mathrm{H}_{2}+$ He Sweep Gas

Also, we have shown that $\mathrm{CsI}$ will react with the materials $\left(\mathrm{Al}_{2} \mathrm{O}_{3}\right.$ and $\left.\mathrm{SiO}_{2}\right)$ of the furnace tube used in our experiments, if adequate oxygen is present. Analysis of $\mathrm{UO}_{2}$ Fuel and Residual Dissolver Solids

The effect of heating fuel to $1500^{\circ} \mathrm{C}$ on subsequent dissolution was examined by dissolving $\mathrm{UO}_{2}$ samples before and after thermal outgassing treatment. No abnormal amounts of plutonium residual solids were found. The results (Table 7 ) show that the residual solids were $0.05 \mathrm{wt} \%, 0.25 \mathrm{wt} \%$, and $0.22 \mathrm{wt} \%$ for as-received fuel, and fuel heated at $1500^{\circ} \mathrm{C}$ for 12 hours in helium or $6 \%$ hydrogen, respectively. The analysis was completed by dissolving weighed 


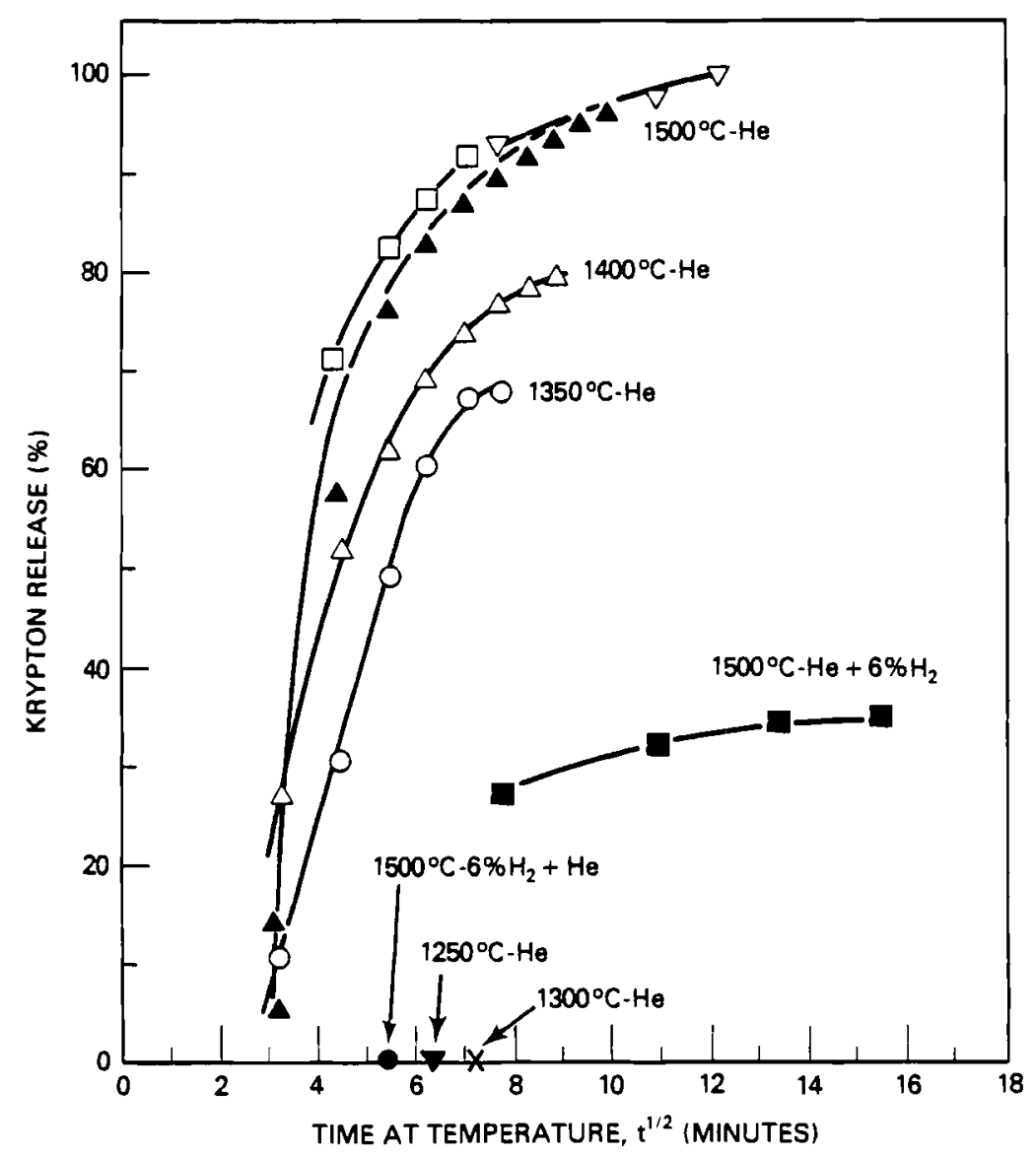

FIGURE 11. Krypton Release as a Function of Temperature, Time and Sweep Gas Composition

$\mathrm{UO}_{2}$ samples in $8 \mathrm{MHNO}_{3}$ for 3 hours at $\sim 100^{\circ} \mathrm{C}$. The resulting dissolver solution was filtered using a preweighed filter paper $(0.025 \mu \mathrm{m})$. The filtered, washed, and weighed solids were then dissolved in $\mathrm{HNO}_{3}$ containing $\mathrm{HF}$ prior to their analysis. The radionuclide analysis for the solids confirmed the weight values.

Cladding Behavior

When zirconium clad, $1-i n$. fuel sections were heated at $1500^{\circ} \mathrm{C}$ for 12 hours, greater than $99 \%$ of the tritium was released from the fuel and cladding. However, the cladding physically and/or chemically hindered the release 
TABLE 7. Analysis of $U 0_{2}$ Fuel Dissolver Solution and Filtered Solids as a Function of Thermal Outgassing Treatment

Conditions: Weighed samples of $40_{2}$, were disolved in $75 \mathrm{~mL} \mathrm{of} 8 \mathrm{M} \mathrm{HNO}_{3}$ for 3 hours at $99^{\circ} \mathrm{C}$. The dissolver solution was filtered using $0.025 \mu \mathrm{m}$ filter paper. The filteredwashed solids were weiyhed and dissolved in $\mathrm{HNO}_{3}+\mathrm{HF}$ prior to analysis.

$1500^{\circ} \mathrm{C}$, He Treated, $12 \mathrm{~h}$

\begin{tabular}{|c|c|c|}
\hline $\begin{array}{l}\text { Dissolver } \\
\text { Solution }\end{array}$ & $\begin{array}{l}\text { Untreated } 100_{2} \\
\mathrm{~d} / \mathrm{m} / \mathrm{g} \cup 0_{2}\end{array}$ & $\frac{10.444 g}{q(a)}$ \\
\hline Cs-134 & $2.54 \mathrm{E} \quad 8$ & -- \\
\hline Cs-137 & $8.07 \mathrm{E} 10$ & -- \\
\hline$E u-154$ & $1.74 \mathrm{E} \quad 9$ & -- \\
\hline$P u-239-240$ & $1.56 \mathrm{E} 9$ & -- \\
\hline CnI-242 & $1.50 \mathrm{E} 7$ & -- \\
\hline $\mathrm{Cm}-244$ & $3.66 \mathrm{E} \quad 9$ & -- \\
\hline$A m-241$ & $4.13 \mathrm{E} 9$ & -- \\
\hline $1-129$ & $2.07 \mathrm{E}-4 \mathrm{~g} / \mathrm{g}$ & -- \\
\hline
\end{tabular}

Solids

Cs-134

Cs-137

Eu-154

Pu-239-240

Cm-242

Cm-244

Am-241

\begin{tabular}{|c|c|}
\hline $1.39 \mathrm{E} 5$ & 0.055 \\
\hline $3.96 \mathrm{E} 7$ & 0.049 \\
\hline $5.70 \mathrm{E} \quad 5$ & 0.033 \\
\hline $8.75 E 5$ & 0.056 \\
\hline $6.25 \mathrm{E} \quad 3$ & 0.042 \\
\hline $1.23 \mathrm{E} \quad 6$ & 0.033 \\
\hline $1.34 \mathrm{E} 6$ & 0.032 \\
\hline
\end{tabular}

Solids Found
2.2928 y U $0_{2}$ Dissolved

$\mathrm{d} / \mathrm{m} / \mathrm{g} \cup 0_{2}-\frac{q(a)}{2}$

-.

4.54E 9

$1.99 \mathrm{E} 9$

$1.72 \mathrm{E} 9$

$1.77 \mathrm{E} 7$

4.20E 9

$4.46 \mathrm{E} 9$

$2.90 E-5 y / g$

$--$

5.6

114

110

118

118

108

14

$\begin{array}{lll}1.79 \mathrm{E} \quad 6 & 0.70\end{array}$

$4.97 \mathrm{E} 8$

0.62

$1.17 \mathrm{E} 6$

0.07

0.12

0.07

$1.12 \mathrm{E} 4$

$2.67 \mathrm{E} 6$

2.83E 6

0.07

\begin{abstract}
$\underline{0.07}$
\end{abstract}
Ave. $=\overline{0.25}$

ND $1500^{\circ} \mathrm{C}, 6 \% \mathrm{H}_{2}+\mathrm{He}, 12 \mathrm{~h}$

$4.1155 \mathrm{~g} \mathrm{VO}{ }_{2} \mathrm{Uissolved}$

$\frac{\mathrm{d} / \mathrm{m} / \mathrm{g} \cup 0_{2}}{2.33 \mathrm{E} 8}-\frac{q(\mathrm{a})}{92}$

$2.33 \mathrm{E} 8-2$

$5.87 \mathrm{E} 10 \quad 73$

$1.89 \mathrm{E} 9 \quad 108$

$1.56 \mathrm{E} 9 \quad 100$

-- -.

$\begin{array}{ll}4.71 \mathrm{E} 9 & 127\end{array}$

$4.58 \mathrm{E} 9 \quad 111$

$8.54 \mathrm{E}-5 \mathrm{~g} / \mathrm{g} \quad 41$

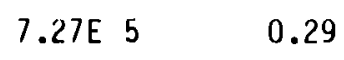

$1.88 \mathrm{E} 8 \quad 0.23$

$9.29 E \quad 6 \quad 0.53$

$1.82 \mathrm{E} 6 \quad 0.12$

-- --

$\begin{array}{ll}3.67 \mathrm{E} 6 & 0.10\end{array}$

$3.45 \mathrm{E} 6 \quad \underline{0.08}$

Ave. $=0.22$

0.20 wt\%

$(8.4 \mathrm{mg})$

(a) * of total in untreated fuel. 
of krypton-xenon. In addition, for both $6 \% \mathrm{H}_{2}+$ He and He-only sweep-gas, the cladding was easily fractured away from the fuel at the conclusion of the experiment (Figure 12). Because the outgassing program was being terminated, no additional tests were completed to determine 1) the minimum temperature and time required to fracture the cladding, and 2) the possibility of $\mathrm{Kr}-\mathrm{Xe}$ release when the exposed fuel is reheated in helium.

Results in Tables 5 and 6 show that >99\% tritium is released from Shippingport $\mathrm{UO}_{2}$ fuel at $1500^{\circ} \mathrm{C}$ for both $6 \% \mathrm{H}_{2}+\mathrm{He}$ and He-only, using powdered $\mathrm{UO}_{2}$, partial pellets, and fuel clad $1-i n$. sections. Tritium is also released from the zirconium cladding.

When the sweep-gas contains $6 \% \mathrm{H}_{2}+\mathrm{He},<20 \%$ of the $\mathrm{Kr}-\mathrm{Xe}$ is released for powder, pellets, and clad sections. However, when the sweep-gas contains only helium, $>95 \%$ of the $\mathrm{Kr}-\mathrm{Xe}$ was released from the $\mathrm{UO}_{2}$ powder and pieces of pellet. When the 1-in. clad fuel section was heated in $\mathrm{He}$, the $\mathrm{Kr}-\mathrm{Xe}$ was not released. Additional tests will be required to determine this cladding effect. Engineering Evaluation

Using the available experimental data, an engineering analysis of the thermal release concept was requested from the General Atomic Company. Their report is included here as an appendix. The design is based on a 0.5 metric ton/day process in order to make the data comparable with existing voloxidation data.

The unique component in the system is probably the heat treatment furnace. The high-temperature furnace is easy to operate and control, has no rotating parts, is remotely serviceable, and requires no additional engineering development. The off-gas treatment system is similar in design to a proven helium purification system for a high-temperature, gas-cooled reactor (HTGR). However, the trapping systems shown in Figures $A .2$ and $A .3$ for iodine, tritium, and noble gases could be replaced by other systems. The absence of oxidants in the gas stream greatly simplifies the fission gas recovery. The preliminary engineering evaluation has shown that the process is feasible with the equipment available on the market at total costs comparable to other head-end processes. 


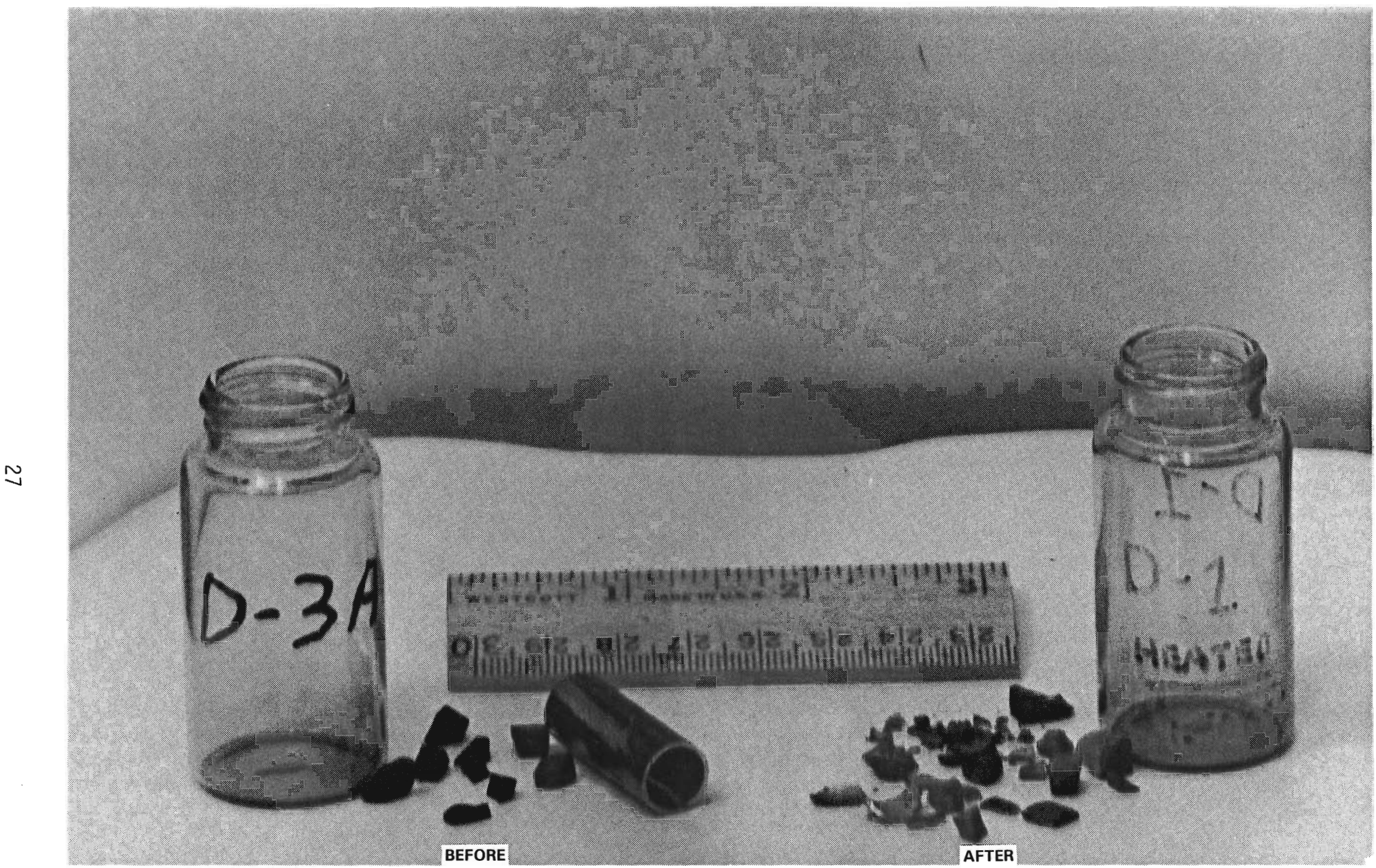

FIGURE 12. Shippingport $\mathrm{UO}_{2} \mathrm{Clad}$ Fuel Section After Heating in Helium at $1500^{\circ} \mathrm{C}$ 
. 


\section{ACKNOWLEDGMENTS}

We would like to thank C. A. Hinman and W. J. Woods of the Hanford Engineering Develoment Laboratory for their help, including the use of their extensively instrumented vacuum outgassing system; C. E. Saari (HEDL) for his analytical assistance; L. D. Maki for typing the report; and S. E. King for her editorial assistance. 



\section{REFERENCES}

Campbell, D. 0., A. P. Malinauskas, and W. R. Stratton. 1981. "Chemical Behavior of Fission Product Iodine in Light Water Reactor Accidents." Nucl. Technol. 53:111.

Hinman, C. A., and 0. D. Slagle. 1978. Ex-Reactor Transient Fission Gas Release Studies, Fuel Pin PNL-2-4." HEDL TME 77-83, Hanford Engineering Development Laboratory, Richland, Washington.

Morgan, L. G., C. L. Matsuzaki, L. A. Bray, and L. L. Burger. 1983. Thermal Outgassing of Irradiated Nuclear Fuel: A Literature Review." PNL-4487, Pacific Northwest Laboratory, Richland, Washington. 


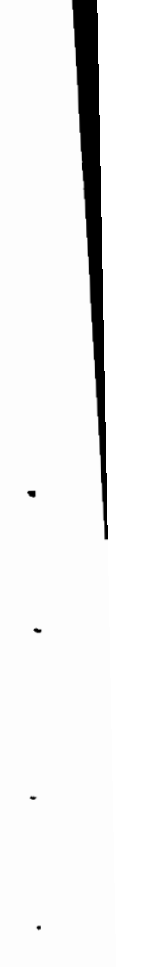


APPENDIX A

SUMMARY OF THERMAL SWEEP-GAS RESULTS 


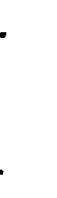


Summary of Results for Sweep-Gas Thermal Outgassing

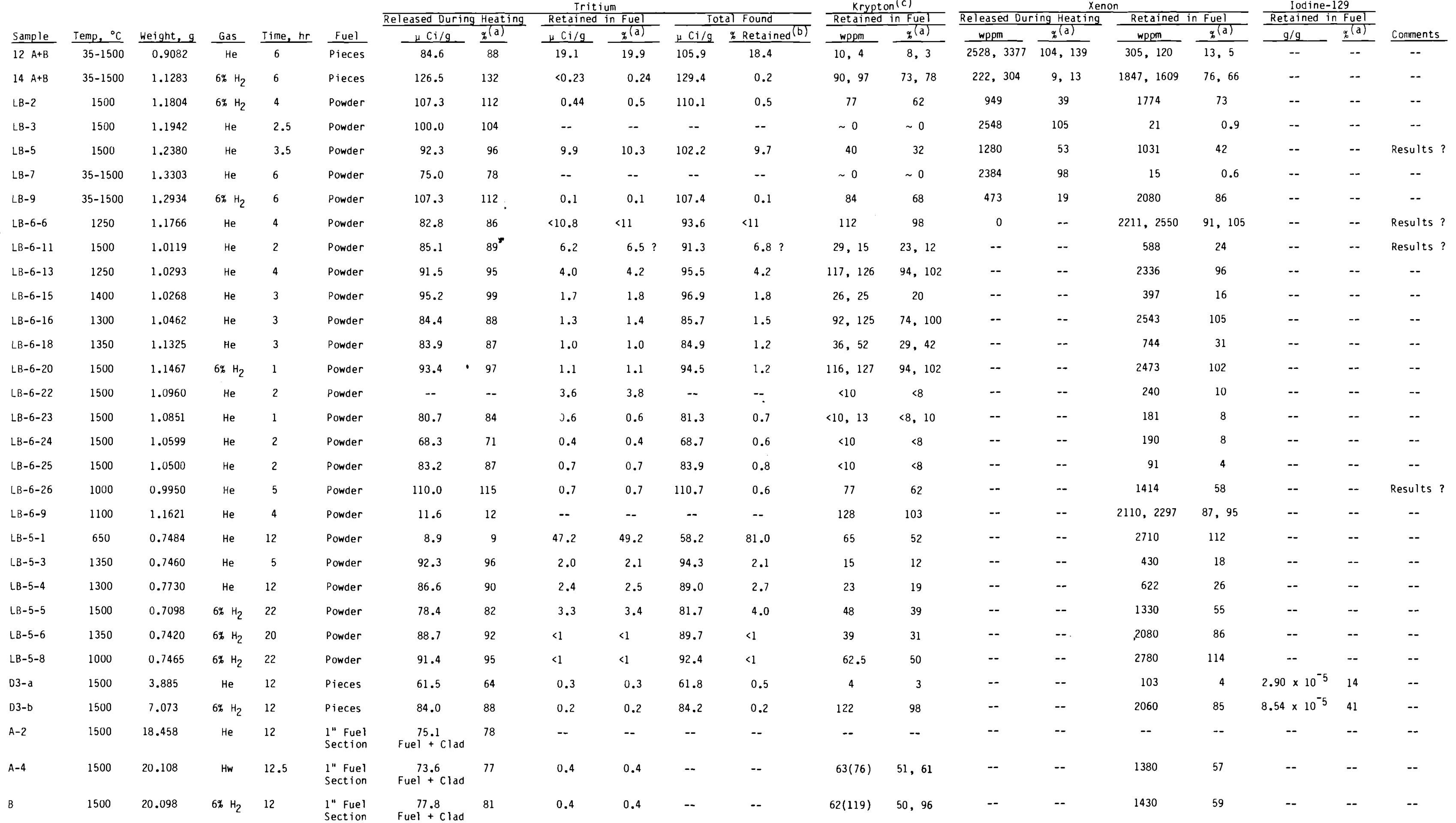

a Based on average val ues (Table 2).
b percent retained in fuel after heat ing based on total found.

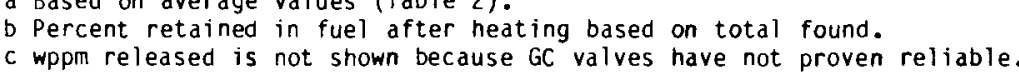




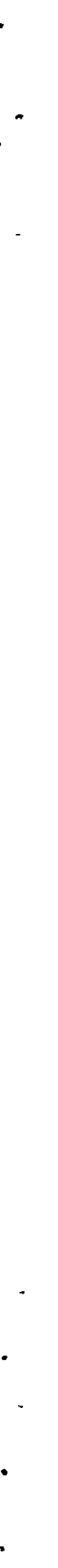


APPENDIX B

THERMAL OUTGASSING ENGINEERING STUDY 


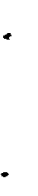


APPENDIX B

THERMAL OUTGASSING ENGINEERING STUDY

\author{
L. J. 01 guin \\ G. E. Benedict \\ R. G. Wilbourn \\ Prepared under Subcontract C-3969-A-Z \\ for Pacific Northwest Laboratory \\ by General Atomic Company \\ San Diego, California 92138
}

August 1982

General Atomic Project 3378 


\section{CONTENTS}

ABSTRACT $\quad \ldots \ldots \ldots \ldots \ldots \ldots \ldots \ldots \ldots \ldots \ldots \ldots \ldots \ldots \ldots \ldots \ldots \ldots \ldots \ldots \ldots \ldots \ldots$

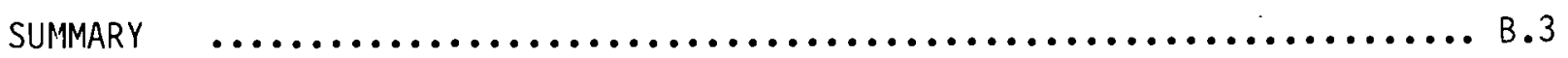

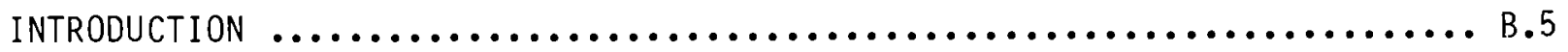

DISCUSSION $\ldots \ldots \ldots \ldots \ldots \ldots \ldots \ldots \ldots \ldots \ldots \ldots \ldots \ldots \ldots \ldots \ldots \ldots \ldots \ldots \ldots \ldots \ldots$

REMOVAL ${ }^{-}$OF TRITIUM FROM AQUEOUS PROCESS STREAMS $\ldots \ldots \ldots \ldots \ldots \ldots \ldots \ldots . \ldots$

REMOVAL OF TRITIUM IN THE DRY HEAD-END OPERATIONS $\ldots \ldots \ldots \ldots \ldots \ldots \ldots . . .$.

Voloxidation Process $\ldots \ldots \ldots \ldots \ldots \ldots \ldots \ldots \ldots \ldots \ldots \ldots \ldots . \ldots . \ldots . \ldots$

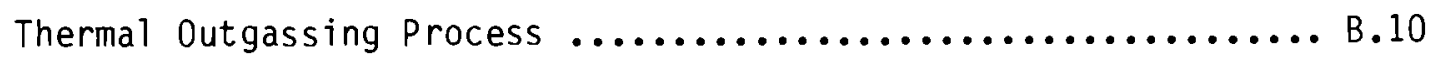

CONCEPTUAL DESIGN $\ldots \ldots \ldots \ldots \ldots \ldots \ldots \ldots \ldots \ldots \ldots \ldots \ldots \ldots \ldots \ldots \ldots \ldots$

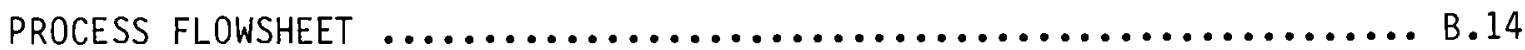

EQUIPMENT DESCRIPTION $\ldots \ldots \ldots \ldots \ldots \ldots \ldots \ldots \ldots \ldots \ldots \ldots \ldots \ldots \ldots \ldots \ldots \ldots \ldots \ldots$

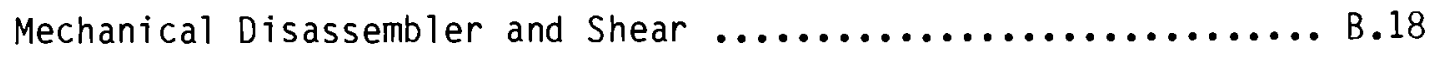

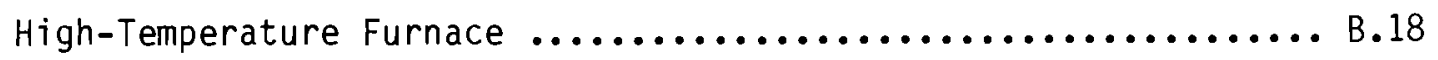

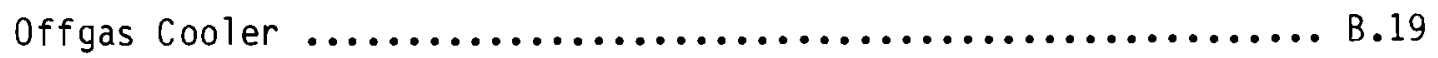

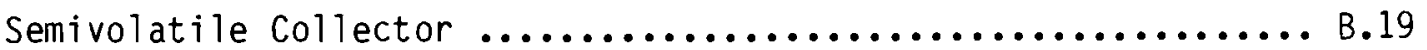

Iodine Adsorber $\ldots \ldots \ldots \ldots \ldots \ldots \ldots \ldots \ldots \ldots \ldots \ldots \ldots \ldots \ldots . \ldots \ldots$

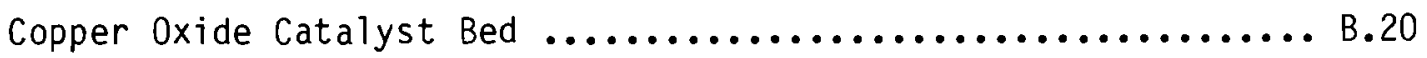

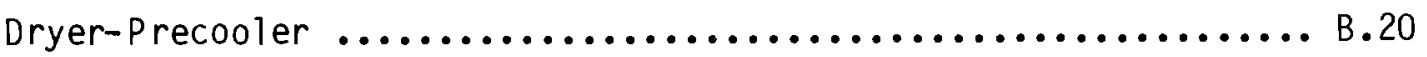

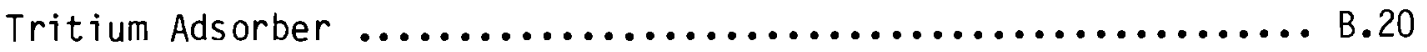

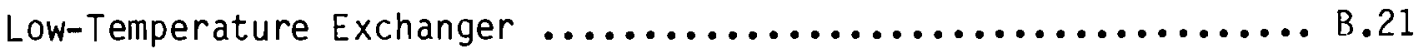

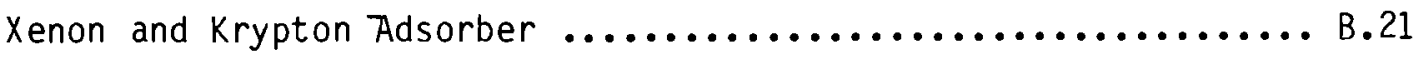

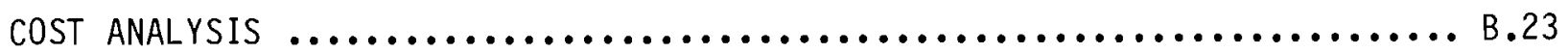

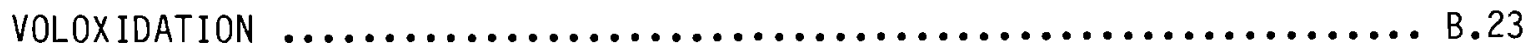

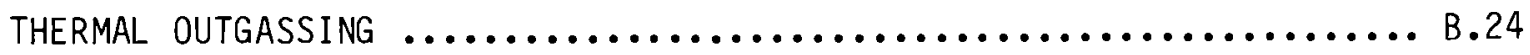




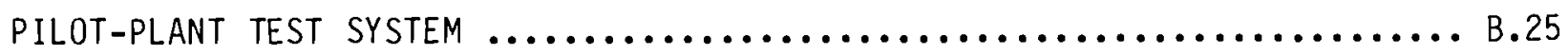

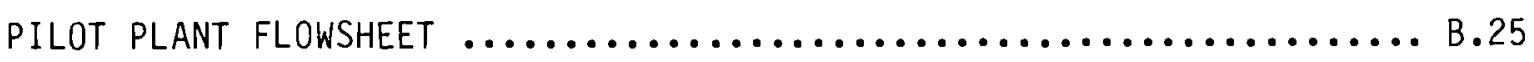

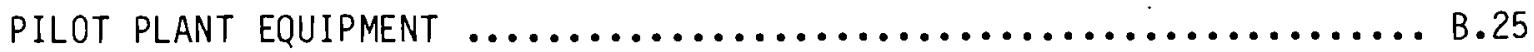

TECHNICAL ASSESSMENT $\ldots \ldots \ldots \ldots \ldots \ldots \ldots \ldots \ldots \ldots \ldots \ldots \ldots \ldots \ldots \ldots \ldots \ldots \ldots \ldots . \ldots \ldots \ldots . \ldots \ldots$

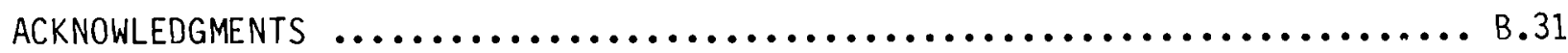

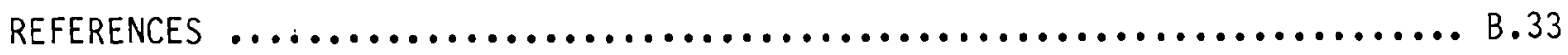




\section{ABSTRACT}

Thermal outgassing is a technically feasible and cost-competitive process to remove tritium in the head-end portion of a light water reactor (LWR) fuel reprocessing plant. This report gives a preliminary conceptual design and a direct cost estimate for a large-scale thermal outgassing system. It also recommends further laboratory-scale development. 
SUMMARY

A pilot-plant thermal outgassing system has been conceptually designed from an engineering analysis of available experimental data. In the thermal outgassing process, tritium and other volatile fission products diffuse from irradiated light water reactor (LWR) fuel exposed to $1500^{\circ} \mathrm{C}$ for 6 hours. A stream of helium sweep gas carries the released fission products to an offgas train where they are selectively separated and retained. The conceptual design requires various unit process steps including fuel rod shearing, fuel rod heat treatment, semivolatile removal, iodine adsorption, conversion of tritium to tritiated water, tritiated water adsorption, and krypton and xenon adsorption.

The direct cost of a 0.5 metric ton/day thermal outgassing system is estimated to be $\$ 1,926,000$ (1982 dollars), including equipment, installation, instrumentation and controls, piping, and services. Major equipment items represent $40 \%$ of the total direct costs, and a contingency fee of $20 \%$ has been applied. Indirect costs, such as engineering design, are included in the cost of the high-temperature furnace. A high-temperature furnace(s) can be manufactured and operated relative to a large-scale 5 metric tons/day process. However, more detailed design is recommended. The costs of the thermal outgassing system appear to be competitive with the voloxidizer costs.

Further research and development efforts are suggested to support the design assumptions regarding fission product diffusion rates, offgas characterization, and adsorber decontamination factors. 


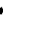




\section{INTRODUCTION}

Irradiated nuclear fuel contains tritium, $3_{H}$, as a waste product. Tritium is a radionuclide of hydrogen with a half-life of about 12.5 years. The tritium present in irradiated LWR fuel is retained in the zirconium fuel cladding and the $\mathrm{UO}_{2}$ fuel pellets. Significant quantities are released downstream of the reactor after the spent fuel is reprocessed.

The presence of tritium in nuclear fuel reprocessing operations can result in its ultimate release from a plant to the environment. Historically, in the absence of regulatory constraints, no attempt was made to collect and store tritium waste during fuel reprocessing. Since tritium is radioactive, future governmental and environmental regulations may impose limits on the permissible amount of tritium released from a fuel reprocessing plant. Consequently, experimental and developmental work has been conducted at Oak Ridge National Laboratory (ORNL) (Goode et al. 1973, 1980) and other sites to 1) define the paths of tritium and other volatile fission products (e.g., ${ }^{85} \mathrm{Kr}$, xenon, and iodine) in the reprocessing flowsheets and 2) design and operate processes and equipment for tritium collection and disposal. Thermal outgassing experimental data were obtained from the Pacific Northwest Laboratory (PNL). The close-out date for available PNL test information was June 29, 1982. 
. 


\section{$\underline{\text { DISCUSSION }}$}

Two general methods are proposed to contain tritium in fuel reprocessing operations: 1) chemical and physical treatments to remove and-collect tritium from the aqueous streams following dissolution and 2) heat treatments to remove and collect tritium prior to fuel dissolution (e.g., voloxidation and thermal outgassing).

REMOVAL OF TRITIUM FROM AQUEOUS PROCESS STREAMS

Possible chemical and physical treatments to remove tritium from aqueous reprocessing streams are referenced below:

1. first cycle, solvent extraction partitioning (Hall and Ward 1975)

2. Chemical exchange (Bebbington and Thayer 1959)

3. combined electrolysis/catalytic exchange (Bixel, Hartzell, and Park 1976)

4. electrolysis (Lin 1972)

5. laser isotope separation (Anderson and Kershner 1976).

If tritium is not removed from nuclear fuel during the dry head-end reprocessing operations, it will be transferred to the process aqueous streams beginning with the dissolution step. Tritium is expected to appear in the aqueous streams as tritiated water. Concentrating, separating, and removing tritium from the aqueous process streams is difficult due to several factors: 1) relatively large volumes of liquids in the aqueous streams, 2) high water/ tritiated water ratios, and 3) similar chemical and physical properties of water and tritiated water.

REMOVAL OF TRITIUM IN THE DRY HEAD-END OPERATIONS

Since removal of tritium from aqueous process streams is difficult to accomplish, alternative methods for managing tritium have been proposed. These alternative methods are dry head-end heat treatments known as voloxidation and thermal outgassing. 
Voloxidation Process

The voloxidation process being developed removes, collects, and retains tritium to enable tritium handling in the dry head-end. This process is based on thermogravimetric studies of $(\mathrm{U}-\mathrm{Pu}) \mathrm{O}_{2}$ fuel oxidation and hot cell tests conducted at various locations during the past 20 years.

In the voloxidation process, tritium is released from $\mathrm{UO}_{2}$ or $(\mathrm{U}-\mathrm{Pu}) \mathrm{O}_{2}$ fuels during oxidation in air at 350 to $650^{\circ} \mathrm{C}$. The fuel residence time at temperature is about 4 hours. Under these conditions, uranium dioxide is restructured to $\mathrm{U}_{3} \mathrm{O}_{8}$, which aids in the evolution of tritium as the oxide. Under optimum conditions, tritium release efficiencies are near 100\%. Voloxidation also decreases the fuel concentrations of other volatile fission products (e.g., ${ }^{85} \mathrm{Kr},{ }^{14} \mathrm{C}$, xenon, and iodine) to lesser extents. Typical values for maximum $85 \mathrm{Kr}$ and iodine release during voloxidation are $\sim 45$ and $\sim 75 \%$, respectively (Goode et al. 1973). Voloxidation does not result in appreciable release of semivolatile fission products from the fuel. Semivolatile fission product release values of $<0.1 \%$ have been reported for ${ }^{106} \mathrm{Ru},{ }^{134} \mathrm{Cs},{ }^{137} \mathrm{Cs}$, ${ }^{125} \mathrm{Sb}$, and ${ }^{144} \mathrm{Ce}$ (Goode et al. 1980). The small amounts of semivolatile fission products that leave the fuel during voloxidation tend to deposit in cold zones downstream of the furnace and do not remain in the system offgas.

Figure B.1 shows a schematic drawing of the voloxidation process (Murbach et al. 1974). The feed to the process consists of Zircaloy-clad uranium oxide fuel. The fuel is sheared into segments and routed to a rotary kiln for heat treatment. The solids exiting the kiln contain the Zircaloy cladding and uranium (in the form of $\mathrm{U}_{3} \mathrm{O}_{8}$ ). The solids are discharged to the dissolver for subsequent dissolution in nitric acid. The shear and rotary kiln off gases are combined and processed through a cyclone and high-efficiency particulate-air (HEPA) filter to remove particulate material. The gas stream is then passed through a catalytic oxidizer at 400 to $600^{\circ} \mathrm{C}$ to ensure conversion of tritium to tritiated water. Following catalytic oxidation, the gas stream is cooled to ambient temperature and passed through a bed of calcium sulfate, then through a bed of molecular sieves to remove the tritiated water from the gas stream by adsorption. The tritiated water is removed from the absorber trap at 200 to 


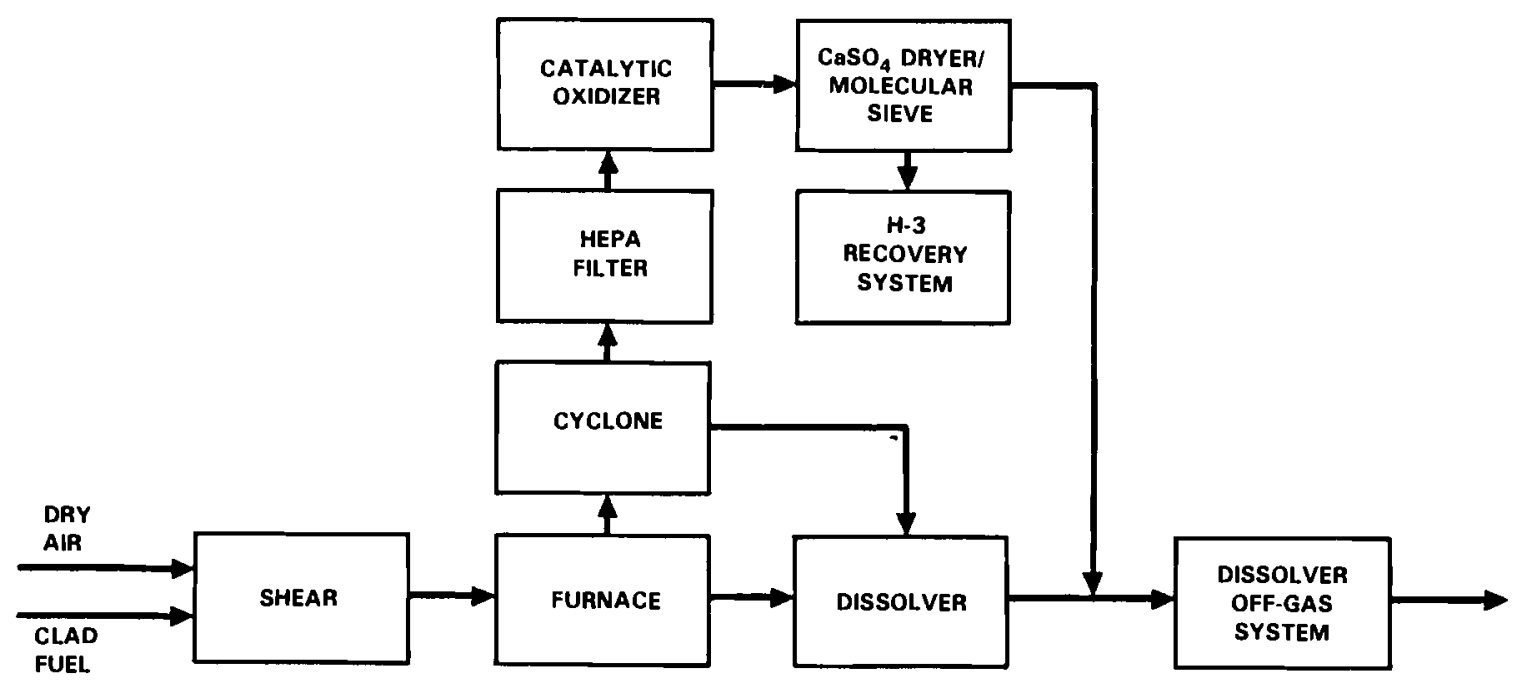

FIGURE B.1. Voloxidation Process Schematic

$300^{\circ} \mathrm{C}$ by the passage of a stream of dry air. The gas stream containing the tritiated water vapor is then cooled to condense the tritiated water, which is collected and stored. Since complete volatilization of krypton, xenon, and iodine is not achieved, no provision is made in the voloxidation process to remove and collect these fission products from the offgas. Krypton, xenon, and iodine will pass through the tritium collection unit and ultimately be handled by the dissolver offgas system.

Several factors affect the voloxidation performance of nuclear fuels. Many of these factors are related to fabrication history and include 1) physical properties (e.g., density, shape, and homogeneity of the fuel), 2) chemical form, and 3) oxide-to-metal ratio. In addition, irradiation parameters also influence fuel voloxidation behavior. Important irradiation parameters are 1) burnup, 2) flux type, 3) $235 \mathrm{U}$ enrichment, and 4) the degree of fuel restructuring in radiation fields (Goode et al. 1973).

Development Status of Voloxidation

Laboratory Studies. Laboratory evaluations of the voloxidation process have been conducted in hot cell test units during the past 10 years. These units generally incorporate a small stainless-steel rotary kiln designed to 
provide tumbling of Zircaloy-clad fuel in a flowing stream of dry air at elevated temperature (Goode et al. 1978).

Engineering-Scale Studies. The successful demonstration of the voloxidation process in laboratory studies led to the design and manufacture of a pilot-scale engineering process unit. The full-scale unit, which can process 0.5 metric tons of nuclear fuel per day, was installed at ORNL in 1978 (Oak Ridge National Laboratory 1978). The large unit has been used to extend and verify data on heat and mass transfer obtained earlier in the smaller units. In addition to a large stainless-steel rotary kiln, the engineering-scale system includes hoppers; vibrating trays; feeding, sampling, and product receiving stations; heat exchangers; and a furnace cooling system.

Thermal Outgassing Process

The thermal outgassing process removes, collects, and retains tritium in the head-end. This process is being evaluated as a possible alternative to voloxidation. Like voloxidation, thermal outgassing is based on laboratory heat treatment studies made with irradiated LWR fuel fragments and on hot cell tests (Campbell and Pattison 1981).

Thermal outgassing is distinguished from voloxidation because thermal outgassing is conducted 1) in a non-oxidizing atmosphere instead of dry air and 2) at higher temperatures (typically 900 to $1500^{\circ} \mathrm{C}$ ) than voloxidation (350 to $\left.650^{\circ} \mathrm{C}\right)$.

In the thermal outgassing process, tritium is removed from nuclear fuels at high temperature in an inert atmosphere. The process conditions promote diffusion of tritium and other fission products (e.g., krypton, xenon, and iodine) through the fuel matrix and subsequently from the fuel. Since the process is non-oxidizing, $\mathrm{UO}_{2}$ does not normally restructure to $\mathrm{U}_{3} \mathrm{O}_{8}$.

The paths of volatile and semivolatile fission products during thermal outgassing have not been completely defined. The results of laboratory studies show that $>99 \%$ of tritium, krypton, and xenon can be removed from $\mathrm{UO}_{2}$ powder at $1500^{\circ} \mathrm{C}$ in $\leqslant 6$ hours with a helium sweep gas. 
Figure $B .2$ shows a schematic drawing for the thermal outgassing of nuclear fuels. The feed to the thermal outgassing process consists of Zircaloy-clad oxide fuel. Following shearing into segments, the fuel will be transferred into "boats" and passed mechanically through a tube furnace maintained at $1500^{\circ} \mathrm{C}$. The boats containing the fuel are passed through a cold zone after thermal treatment prior to discharge of the fuel to the dissolver. The furnace offgas is passed sequentially through a heat exchanger, filter, and hightemperature charcoal adsorber bed. Semivolatile fission products (e.g., ruthenium and cesium) will deposit in the filter, the heat exchanger, -and the lower stages of the high-temperature charcoal adsorber bed. Iodine will be retained in the high-temperature adsorber bed. Following iodine removal, the offgas is passed through a heated cupric oxide trap (to convert tritium to tritiated water), cooled, and passed through a molecular sieve adsorber bed for tritiated water removal. Next the offgas is cooled further, and krypton and

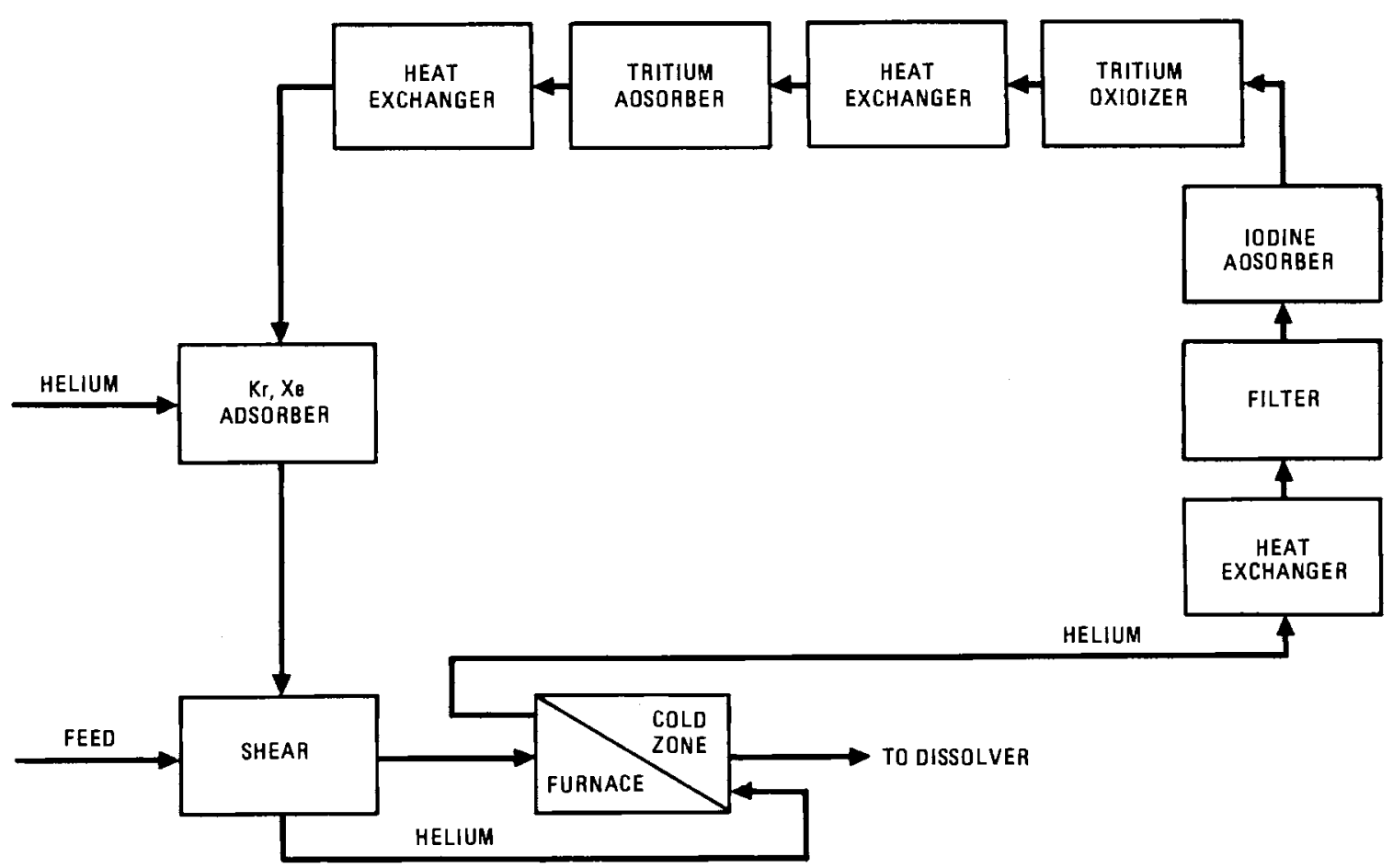

FIGURE B.2. Thermal Outgassing Process Schematic 
xenon are removed in a cryogenic trap which contains charcoal. As presently planned, the process helium sweep gas will be contained in a closed loop and recycled.

Development Status of Thermal Outgassing

The thermal outgassing process has not been as extensively developed as the voloxidation process. The anticipated performance of the thermal outgassing process has been extrapolated from bench-scale experimental results. 
CONCEPTUAL DESIGN

Spent fuel treatment and offgas decontamination comprise the two main systems in the thermal outgassing conceptual design. Design calculations are based on a pilot-plant capacity of 0.5 metric ton/day of uranium. The Consolidated Fuel Reprocessing Program - Hot Experimental Facility (CFRP-HEF) conceptual design (Oak Ridge National Laboratory 1981) for the voloxidation process is also based on the same capacity. Initial process requirements for spent fuel treatment include disassembly of the fuel elements and segmentation of the fuel rods into 1-in.-long pieces. Excess metal from the fuel element assembly is discarded as scrap waste.

For this study, the Diablo Canyon reactor was selected as a source of typical LWR reference fuel. An Oak Ridge National Laboratory (ORNL) report (1970) provides detailed information on the amounts of significant fission products present in the spent reference fuel, based on an average burnup of 33,000 MWd/metric ton of uranium and a postirradiation decay time of 1 year. The final stage of spent fuel treatment is the high-temperature thermal outgassing process. The feasibility of tritium removal via thermal outgassing is supported by hot cell test data from PNL.

The offgas treatment system removes tritium, iodine, krypton, xenon, and semivolatile fission products generated during the head-end spent fuel treatment operations. Small quantities of fission products are known to migrate to the boundary between the Zircaloy cladding and the uranium oxide fuel matrix. Kullen, Trevorrow, and Steindler (1975) estimate that between 0.1 and $9.0 \%$ of the tritium is released during mechanical shearing and that as much as $10 \%$ of the noble gases is also released. For design purposes, the offgas composition from the shearing operation was assumed to contain an average of $5 \%$ of the total tritium inventory and $10 \%$ of the krypton and xenon inventory. An inert helium sweep gas at 2 psig carries the contaminants to the combined furnace/ cooler where the stream flows countercurrent across trays loaded with segmented fuel rods. The furnace offgas stream contains $100 \%$ of the tritium, iodine, krypton, and xenon inventories as well as small quantities of other fission products. The conceptual design of the offgas treatment system is based on an 
existing helium purification system in operation at the Fort St. Vrain nuclear generating station in Colorado. The smaller scale system described herein will decontaminate the helium sweep gas, and the resulting purified gas will be compressed and recycled in a closed-loop process.

\section{PROCESS FLOWSHEET}

The thermal outgassing system is comprised of the following unit processes for spent fuel treatment and offgas decontamination:

1. fuel rod shearing

2. fuel rod heat treatment

3. semivolatile removal

4. iodine adsorption

5. conversion of tritium to tritiated water

6. tritiated water adsorption

7. krypton and xenon adsorption.

Figure B.3 shows the sequence of these unit operations in a process diagram. The material balance table in the figure presents individual stream compositions and their respective operating pressures and temperatures.

Treatment of LWR spent fuel begins with disassembly of the fuel elements and subsequent segmentation of the fuel rods. The chopped fuel rods are loaded into alumina trays and passed through a $1500^{\circ} \mathrm{C}$ furnace at a rate of four trays per hour. Each tray has a 6 hour residence time in the furnace. Thermal outgassing of tritium and other volatile fission products occurs at this stage. Helium sweep gas from the shear passes countercurrent through the cooler and furnace. Countercurrent flow limits back-diffusion of fission product vapors into the fuel rod cooler where they would otherwise deposit on the cold surfaces. Following heat treatment, the tritium-depleted fuel rods are cooled and transferred to the dissolver. 


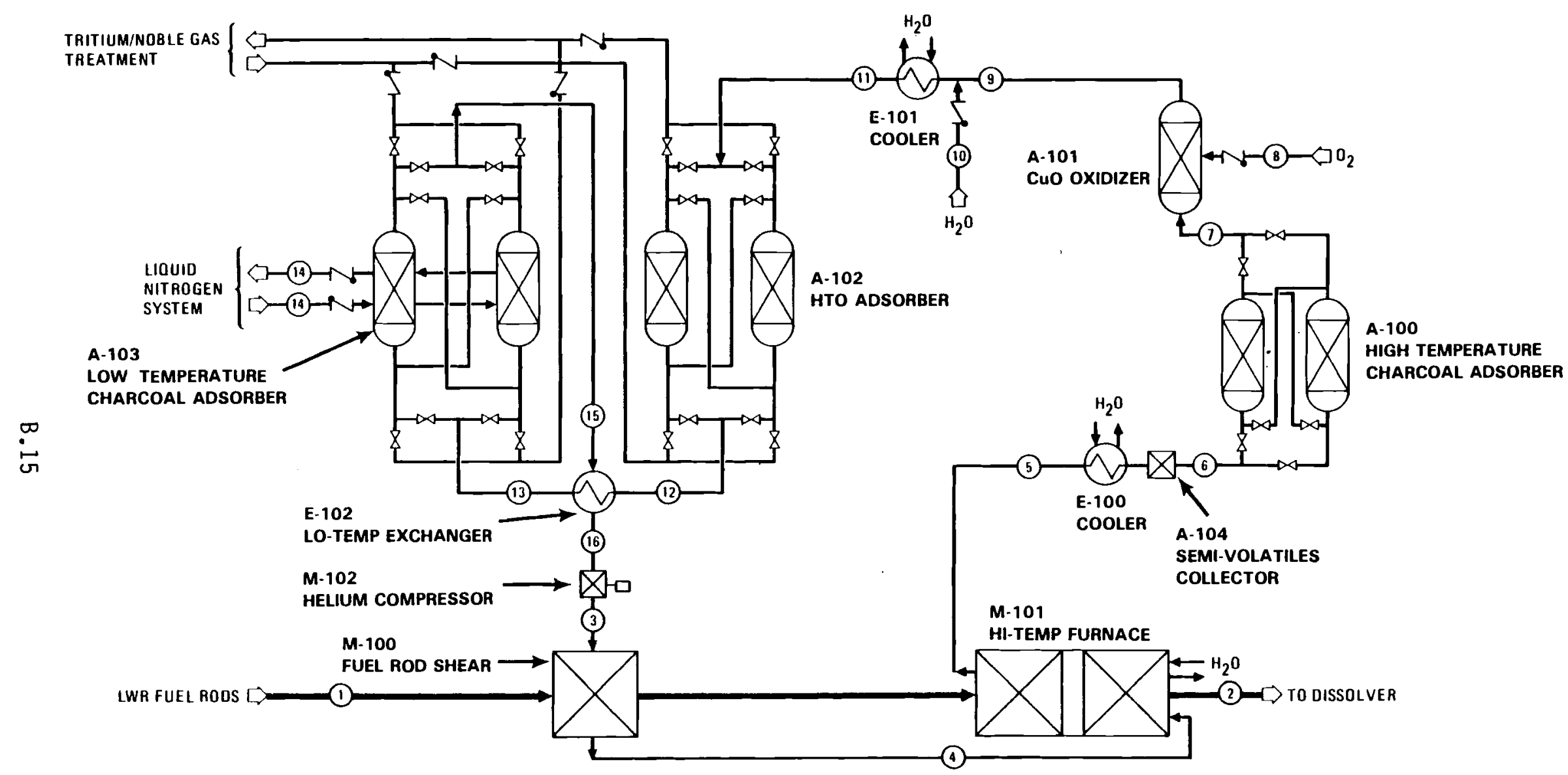

FIGURE B.3. Process Flow Diagram for Thermal Outgassing 


\begin{tabular}{|c|c|c|c|c|c|c|c|c|c|c|c|c|c|c|c|c|}
\hline STREAM NUMBER & 1 & 2 & 3 & 4 & 5 & 6 & 7 & 8 & 9 & 10 & 11 & 12 & 13 & 14 & 16 & 16 \\
\hline STREAM NAME & $\begin{array}{c}\text { SHEAR } \\
\text { REED } \\
\end{array}$ & $\begin{array}{c}\text { DISSOLVER } \\
\text { FEED } \\
\end{array}$ & $\begin{array}{l}\text { PURIFIED } \\
\text { HELIUM }\end{array}$ & \begin{tabular}{|l} 
SHEAA \\
OFF-GAS
\end{tabular} & $\begin{array}{l}\text { FUANACE } \\
\text { OffF-GAS } \\
\end{array}$ & $\begin{array}{c}\text { HI.TEMP } \\
\text { ADSORBEF } \\
\text { INLEI }\end{array}$ & $\begin{array}{c}\text { OXIDIZER } \\
\text { IMLET } \\
\end{array}$ & OXYGEN & $\begin{array}{l}\text { OXIDIZER } \\
\text { PRODUCT }\end{array}$ & 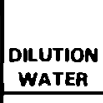 & $\begin{array}{c}\text { HTO } \\
\text { ADSOROREA } \\
\text { INLET }\end{array}$ & \begin{tabular}{|c|} 
HTO \\
AOSOABEA \\
PROOUCT
\end{tabular} & \begin{tabular}{|l} 
LO-TEMP \\
ADSORER \\
NWLET \\
\end{tabular} & $\begin{array}{l}\text { LUQUID } \\
\text { UITROGEN }\end{array}$ & $\begin{array}{l}\text { LO-TEMP } \\
\text { ADSORER } \\
\text { PRODUCT }\end{array}$ & $\begin{array}{c}\text { COMPAESSOR } \\
\text { NLLET }\end{array}$ \\
\hline TEMPERATURE ( ${ }^{\circ} \mathrm{C}$ ) & 21 & 50 & 40 & 40 & 1600 & 370 & 370 & 21 & 370 & 21 & 60 & 60 & .180 & .200 & 190 & 40 \\
\hline PAESSURE (PSIA) & 14.7 & 14.7 & 16.7 & 16.7 & 16.7 & 18.4 & 18.2 & 25 & 18.0 & 25 & 15.2 & 15.2 & 15.1 & 185 & 16.0 & 14.9 \\
\hline COMPONENTS & & & & & & & & & & & & & & & & \\
\hline MW $\quad$ lg/hrt & & & & & & & & & & & & & & & & \\
\hline $4 \quad \mathrm{H}_{0}$ & & & 400 & 400 & 400 & 400 & 400 & & 400 & & 400 & 400 & 400 & & 400 & 400 \\
\hline $3(22) T\left(T_{2} \mathrm{O}\right)$ & 0.0015 & & & $7.5 \times 10^{-6}$ & 0.0015 & 0.0015 & 0.0015 & & 10.0055 & & 10.00561 & & & & & \\
\hline $18 \quad \mathrm{H}_{2} \mathrm{O}$ & & & & & & & & & & 5.6 & 5.5 & 0.00055 & & & & \\
\hline $85 \quad K_{r}$ & 8.1 & & & 0.8 & 8.1 & 8.1 & 8.1 & & 8.1 & & 8.1 & B. 1 & 8.1 & & & \\
\hline $134.2 x_{\theta}$ & 118.3 & & & 11.8 & 118.3 & 118.3 & 118.3 & & 118.3 & & 118.3 & 118.3 & 118.3 & & & \\
\hline 128.71 & 5.9 & & & 0 & 6.9 & 5.9 & & & & & & & & & & \\
\hline FP (SOLDS) & 032.8 & TBD & & & & & & & & & & & & & & \\
\hline $\begin{array}{ll}91 & \text { Z1RCALOY } \\
270 & \mathrm{UO}_{2} \\
32 & 0_{2}\end{array}$ & $\begin{array}{r}2280.2 \\
23634.5\end{array}$ & $\begin{array}{l}2280.2 \\
23634.6\end{array}$ & & & & & & 0.004 & & & & & & & & \\
\hline $28 \quad 40 . N_{2}$ & & & & & & & & & & & & & & TOD & & \\
\hline FLOWRATES: & & & & & & & & & & & & & & & & \\
\hline ACFH & & & 79.8 & 79.9 & 456.9 & 168.7 & 170.6 & & 172.9 & & 90.5 & 91.4 & 26.5 & & 23.6 & 89.5 \\
\hline SCFH $\left.10^{\circ} \mathrm{C}, 1 \mathrm{~atm}\right)$ & & & 79.1 & 79.2 & 79.9 & 79.9 & 79.8 & $1 \times 10^{4}$ & 79.9 & & 80.1 & 79.9 & 79.9 & & 79.1 & 79.1 \\
\hline $\mathrm{g} / \mathrm{hr} \mathbf{r}$ & 26680 & 28369 & 400 & 412.8 & 532.3 & 532.3 & 526.4 & 0.004 & 526.4 & 6.5 & 631.9 & 526.4 & 200.4 & & 400 & 400 \\
\hline $\mathrm{l} / \mathrm{h} / \mathrm{hr}$ & 58.8 & 58.2 & 0.9 & 0.9 & 1.2 & 1.2 & 1.2 & & 1.2 & 0.01 & 1.2 & 1.2 & 0.5 & & 0.9 & 0.9 \\
\hline g.mol/hr & & & 100.0 & 100.1 & 101.0 & 101.0 & 100.9 & $1.3 \times 10^{-4}$ & 101.0 & 0.3 & 101.3 & 101.0 & 101.0 & & 100.0 & 100.0 \\
\hline
\end{tabular}

FIGURE B.3. (contd) 
The offgas train decontaminates the helium sweep gas and ultimately returns it to the process system. The maximum concentrations of contaminants in the offgas stream are as follows:

\begin{tabular}{lc}
\multicolumn{1}{c}{ Impurity } & Concentration, ppm \\
\cline { 1 - 1 } Tritium & 5 \\
Iodine & 455 \\
Krypton & 940 \\
Xenon & 8700 \\
Semivolatiles & To be determined
\end{tabular}

Semivolatiles condense in the offgas cooler and the semivolatile collector immediately downstream of the furnace. These two equipment items are replaced when the buildup of fission products causes excessive generation of decay heat.

Chemisorption of iodine onto alkali-metal-impregnated charcoal occurs next in the offgas train. The iodine adsorbers provide an iodine decontamination factor of $10^{4}$.

Tritium leaving the iodine adsorbers is converted to tritiated water in a copper oxide catalyst bed. Oxygen is supplied as necessary to regenerate the reduced catalyst, although Figure B.3 shows a continuous flow. The tritiated water is then isotopically diluted by water injection to a ratio of 1000 to 1 and cooled to $50^{\circ} \mathrm{C}$. Tritiated water vapor is ultimately removed from the helium carrier gas by adsorption on molecular sieve material. When breakthrough occurs, the tritium adsorbers are independently regenerated and returned to service.

Krypton and xenon are the major contaminants remaining in the helium stream at this point in the offgas treatment system. The helium is cooled by a low-temperature gas-to-gas exchanger to $-180^{\circ} \mathrm{C}$ against cold purified helium. The cold helium passes through cryogenic charcoal adsorbers to remove the fission-produced noble gases (krypton and xenon). When breakthrough occurs, the adsorbers are either independently regenerated or replaced. 
The ultimate disposition of the tritium, krypton, and xenon in the helium regeneration stream is beyond the scope of this study.

Finally, the purified helium stream is compressed to 2 psig and returned to the fuel rod shear. This completes the closed-loop helium sweep-gas cycle.

\section{EQUIPMENT DESCRIPTION}

Major components in the thermal outgassing process consist of a mechanical fuel rod disassembler and shear, a high-temperature furnace with outlet solids cooler, an off-gas filter, two water-cooled heat exchangers, dual iodine adsorbers, a copper oxide catalyst bed, dual tritiated water adsorbers, a lowtemperature exchanger, and dual cryogenic adsorbers. These components are described below and shown in Figure B.3.

Mechanical Disassembler and Shear (M-100)

The mechanical disassembly and shearing equipment is common to both the voloxidation and the thermal outgassing processes. The CFRP-HEF conceptual design of these two systems provides sufficient information regarding their complexity and technical uncertainty. However, the requirement for a helium sweep-gas stream in the shear is different. Offgas from the mechanical disassembler will be treated separately in the dissolver offgas treatment system. An ORNL report (1981) describes this equipment in detail.

High-Temperature Furnace (M-101)

The design of the $1500^{\circ} \mathrm{C}$ furnace is critical to the thermal outgassing process. Furnace design specifications were provided to the Harper Electric Furnace Corporation (HEFC) for their feasibility evaluation relative to the desired operating conditions and remote maintenance capabilities. The HEFC is experienced in hot-cell applications and is therefore familiar with special requirements of servicing equipment with remote manipulators. According to HEFC, a high-temperature furnace suitable for thermal outgassing of LWR fuel rods can be manufactured. The furnace is designed to process 0.5 metric ton/ day of uranium at a constant temperature of $1500^{\circ} \mathrm{C}$. The heating zone is $30 \mathrm{ft}$ in length with a chamber cross section of $12 \times 2.5 \mathrm{in}$. Silicon carbide heating 
elements and standard insulation are adequate for maintaining $1500^{\circ} \mathrm{C}$ in an inert helium atmosphere. A design pressure of 2 psig precludes in-leakage of air. The sweep-gas linear velocity at operating conditions is estimated to be $1 \mathrm{ft} / \mathrm{s}$. Segmented fuel rods will travel through the furnace in alumina trays. Double door (metal-to-metal cam-lock sealed) purge changers are provided at the entrance and exit ends of the furnace, with specialized tray-pushing mechanisms.

Segmented fuel rods exiting the furnace must be cooled prior to the dissolution step. A $20-\mathrm{ft}-1$ ong cooling section following the furnace is designed to reduce the solids temperature from 1500 to $50^{\circ} \mathrm{C}$.

Offgas Cooler $(E-100)$

The offgas cooler reduces the furnace exit gas temperature from 1500 to $370^{\circ} \mathrm{C}$. Contaminated helium sweep gas passes through the tube side of a watercooled, 1-1 single-pass, shell and tube heat exchanger. The cooler has a heat transfer area of $10 \mathrm{ft}^{2}$ with a heat duty of $135,000 \mathrm{Btu} / \mathrm{h}$, and is constructed of stainless steel.

Semivolatile Collector $(A-104)$

This high-temperature offgas filter provides a high surface area for deposition of semivolatile fission products. The filter is a 6-in. SCH 40s stainless-steel column containing $4 \mathrm{ft}$ of stainless-steel-mesh packing material. A water-cooling jacket may be required to remove decay heat and prolong service life between change-outs.

Iodine Adsorber $(A-100)$

This high-temperature adsorber provides for the chemisorption of iodine onto alkali-metal-impregnated charcoal. The loading capacity of the activated charcoal is directly related to the stoichiometric ratio of alkali metal to iodine. An average of 4 wt\% alkali metal is impregnated on the charcoal. Either potassium or sodium is recommended as the alkali metal. The iodine adsorber column requires $5.5 \mathrm{ft}^{3}$ of activated charcoal, based on a 3-month replacement period ( 65 operating days) and an assumed volatility of $100 \%$ iodine. The column is a 10-in. SCH 40s pipe, $10 \mathrm{ft}$ in length. Installation of 
two iodine adsorbers in series allows a single change-out without operational shutdown and also assures a decontamination factor on the order of $10^{4}$.

Silver Exchanged Faujasite $(A g X)$ is an alternative sorbent material for iodine removal. It generally operates at temperatures to $500^{\circ} \mathrm{C}\left(1000^{\circ} \mathrm{C}\right.$ in some tests). The cost of $\mathrm{AgX}$ is $\sim \$ 60 / \mathrm{kg}$, or 20 times the cost/unit weight of alkali-metal impregnated charcoal. The iodine adsorption capacity is $\sim 15$ times higher per gram of sorbent when compared to charcoal.

Silver-Nitrate-Impregnated Amorphous Silica (AC-6120®) has a limitation of $150^{\circ} \mathrm{C}$. The process off-gas stream is $370^{\circ} \mathrm{C}$. The cost of $A C-6120$ is $\$ 187 / \mathrm{kg}$, or more than 60 times the cost/unit weight of charcoal.

Charcoal is acceptable to the thermal outgassing process since $\mathrm{NO}_{\mathrm{x}}$ is not present. Charcoal sells for $\$ 3 / \mathrm{kg}$ and can be operated at $370^{\circ} \mathrm{C}$. Copper Oxide Catalyst Bed $(A-101)$

Tritium entering the copper oxide bed is converted to tritiated water. The catalyst is in the form of 1/8-in. high-activity alumina extrudate containing 10 wt\% copper oxide. The oxidizer bed is a 6 -in. SCH 40 s stainless-steel column, $5 \mathrm{ft}$ in length. The $1 \mathrm{ft}^{3}$ volume of catalyst can be regenerated as necessary by purging with an oxygen stream.

Dryer Precooler $(E-101)$

The precooler for the tritiated adsorbers reduces the sweep gas temperature from 370 to $50^{\circ} \mathrm{C}$. Contaminated helium passes through the tube side of a water-cooled, 1-1 single-pass, shell and tube heat exchanger. The required heat transfer surface area is $60 \mathrm{ft}^{2}$, assuming a $\mathrm{flow}$ rate of $10 \mathrm{gal} / \mathrm{min} \mathrm{cool}-$ ing water.

Tritium Adsorber $(A-102)$

Each tritiated water adsorber contains 117 lb of 5 \& molecular sieve material ( 8 to 12 mesh beads) and is designed to provide a 3-month regeneration period per adsorber. Each column is an 8-in. SCH 40 s stainless-steel pipe, $7.5 \mathrm{ft}$ in length. Two molecular sieve adsorbers installed in series allow one adsorber to remain on line while the other adsorber is being regenerated. 
During normal operation, however, both adsorbers are in use. Elevatedtemperature helium is used to regenerate the beds. Low-Temperature Exchanger (E-102)

The low-temperature exchanger has a heat duty of $500 \mathrm{Btu} / \mathrm{h}$ and requires a heat transfer surface area of $3 \mathrm{ft}^{2}$. Contaminated helium passes through the tube side, and purified helium passes through the shell side of a 1-1 singlepass, shel1 and tube heat exchanger.

Xenon and Krypton Adsorber (A-103)

The cryogenic adsorber is similar in design to a double-pipe heat exchanger with activated charcoal in the inner pipe and liquid nitrogen in the annular jacket. Radiolytically induced ozone formation in cryogenic adsorbers has been extensively studied by General Atomic Company. Proprietary experimental data confirm that ozone formation will increase at a linear rate in molecular sieve adsorption material. These data also show that with cryogenic charcoal adsorption material, a competing ozone decomposition reaction occurs. The resultant concentration of ozone is thereby maintained below hazardous levels.

At saturated conditions, the krypton and xenon loading capacities are $0.91 \mathrm{~b}$ krypton and $1.31 \mathrm{~b}$ xenon/1b of charcoa1. The active surface area of the charcoal is approximately $200 \mathrm{~m}^{2} / \mathrm{g}$. The adsorber requires $117 \mathrm{lb}$ of charcoal $\left(3.9 \mathrm{ft}^{3}\right)$, assuming $100 \%$ release of the noble gases from LWR fuel rods and a 1 month regeneration or replacement period. Dual adsorbers installed in series provide a higher decontamination factor and allow independent regeneration or replacement. Elevated-temperature helium regenerates the adsorbers. Each adsorber is an 8-in. SCH 40 s pipe, $11 \mathrm{ft}$ in length. 


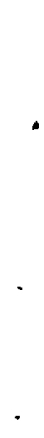




\section{COST ANALYSIS}

The direct costs of the voloxidation and thermal outgassing systems are based on 1982 dollars, including a 20\% contingency factor. The cost of the voloxidation system includes a complete off-gas purification system to recover tritium, iodine, noble gases, and other semivolatile fission products. All costs reported herein for either system are relative to a production capacity of 0.5 metric ton/day of uranium.

VOLOXIDATION

Grimes et al. (1982) provides cost data from Oak Ridge National Laboratory for a combined 8 metric ton/day voloxidizer and tritium recovery system. The tritium recovery system includes a catalytic converter, gas cooler, chiller, knockout pot, two molecular sieve beds, and a tritium surge tank. The ORNLrecommended scaling factor of 0.7 was applied to the referenced costs to allow a cost comparison to the 0.5 metric ton/day thermal outgassing system. The design and installation costs associated with the voloxidizer are assumed to be independent of capacity. The direct cost of the voloxidizer installation and tritium recovery system is also assumed to include costs for instrumentation and control, piping, electrical, etc. Table B.1 shows the adjusted voloxidation system costs.

TABLE B.1. Voloxidation Costs(a)

\begin{tabular}{|c|c|c|}
\hline Item & & Cost \\
\hline Voloxidation fabrication & $\$$ & 345,000 \\
\hline Voloxidation installation & & 591,000 \\
\hline Tritium recovery system & & 345,000 \\
\hline Engineering design & & 594,000 \\
\hline Total & & $, 875,000$ \\
\hline
\end{tabular}

(a) Includes $20 \%$ contingency fee. 
Development of the voloxidizer is not yet completed. As a result, an additional \$594,000 in estimated indirect engineering design costs must be applied (Grimes et al. 1982), for a total of $\$ 1,875,000$ to recover tritium in a 0.5 metric ton/day voloxidation system.

THERMAL OUTGASSING

Table B.2 breaks down the total direct costs related to the thermal outgassing conceptual design. Major equipment costs do not include costs for the mechanical fuel element disassembler and fuel rod shear, since these items are also common to the voloxidation system.

Indirect costs, such as engineering design, are already factored into the purchase price of the high-temperature furnace and fuel rod cooler, and no additional costs are required. Therefore, the 0.5 ton/day thermal outgassing system including the off-gas decontamination system has a total cost of $\$ 1,926,000$.

TABLE B.2. Thermal Outgassing Direct Costs $(a)$

\begin{tabular}{lrr}
\multicolumn{1}{c}{ Item } & \multicolumn{1}{c}{ Cost } \\
\cline { 1 - 1 } Equipment & & 770,000 \\
Installation & 385,000 \\
Instrumentation and controls & & 193,000 \\
Piping & 289,000 \\
Electrical & & 193,000 \\
Services & 96,000 \\
Total & $\$ 1,926,000$
\end{tabular}

(a) Includes $20 \%$ contingency fee. 


\section{PILOT-PLANT TEST SYSTEM}

This section describes a conceptual pilot-plant test system to be used to verify design assumptions and identify potential scaleup problems.

\section{PILOT PLANT FLOWSHEET}

The pilot-plant-scale thermal outgassing system is based on a modified version of the engineering-scale design. Major process modifications of the smaller system include 1) batch-mode processing of the fuel, 2) once-through helium flow, and 3) exclusion of the noble gas adsorbers.

Figure B.4 shows a schematic of the hot cell test system, and Table B.3 presents the material balance. Initially, the furnace is charged with twenty 1-in. segments of $\mathrm{clad}$ spent fuel and heat treated at $1500^{\circ} \mathrm{C}$ for 6 hours. Helium carrier gas passes through the product cooler and furnace muffle tube at a linear velocity of $1 \mathrm{ft} / \mathrm{s}$. This velocity is equivalent to the full-sized engineering-scale unit.

After it passes through the furnace, the contaminated off-gas stream passes successively through a semivolatile collector, iodine adsorber, tritium oxidizer, heat exchanger, and tritiated water adsorber. The exit gas stream contains helium and traces of noble gases. Xenon and krypton adsorption tests were conducted previously by General Atomic Company, and further studies in this area are not required.

\section{PILOT PLANT EQUIPMENT}

A zoned tube furnace supplied by Harper Electric Furnace Company was selected for this process. The furnace has a 3-in. i.d. muffle with a 24-in. heated zone, an exit water-cooled section, and an entrance purge changer for a controlled helium atmosphere.

The semivolatile collector is a 1-1/2-in. SCH 40 s pipe, $1 \mathrm{ft}$ in length. A cooling water jacket is provided externally, and stainless-steel mesh is the internal packing material. 


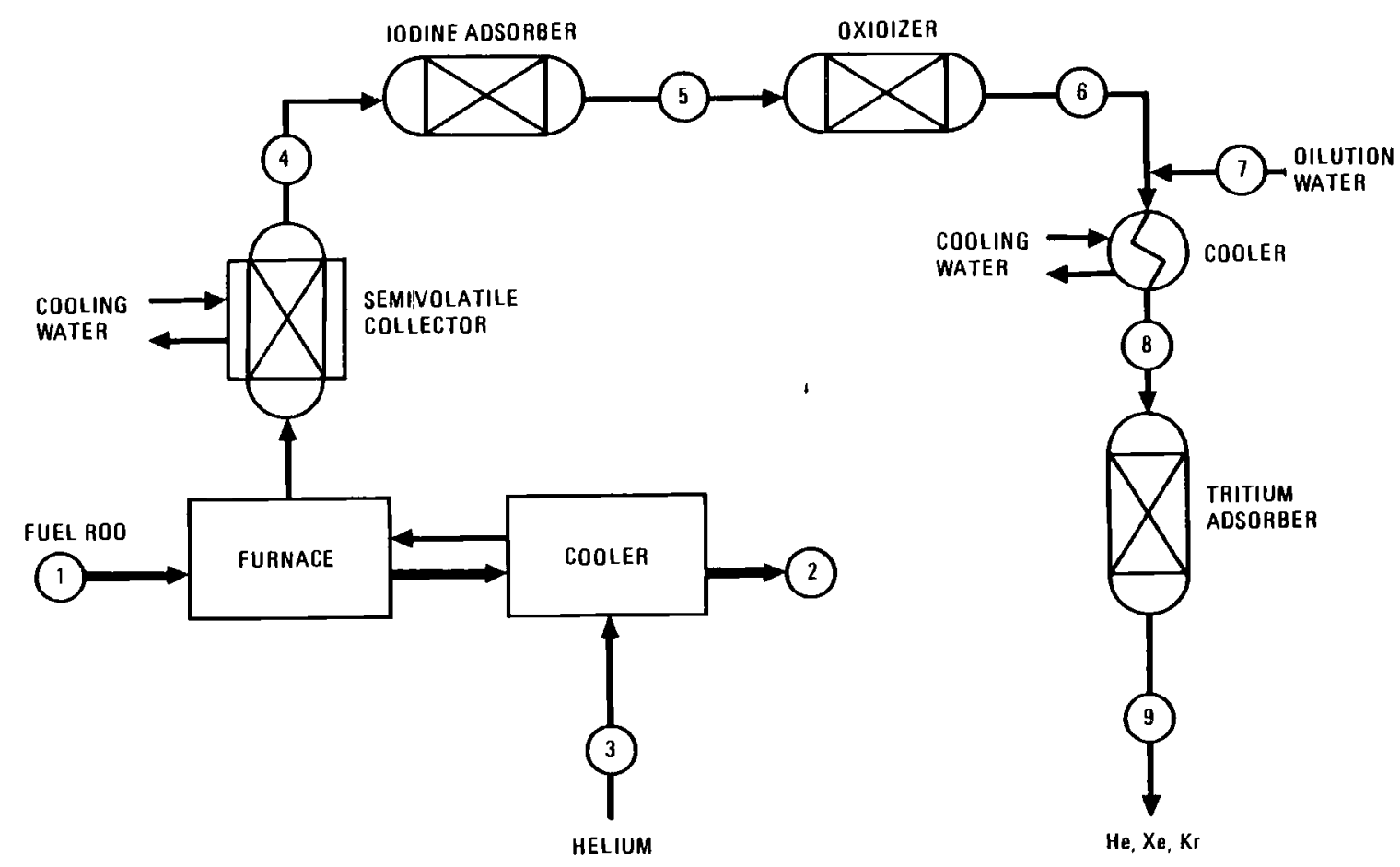

FIGURE B.4. Hot Cell Test System 
TABLE B.3. Pilot Plant Material Balance

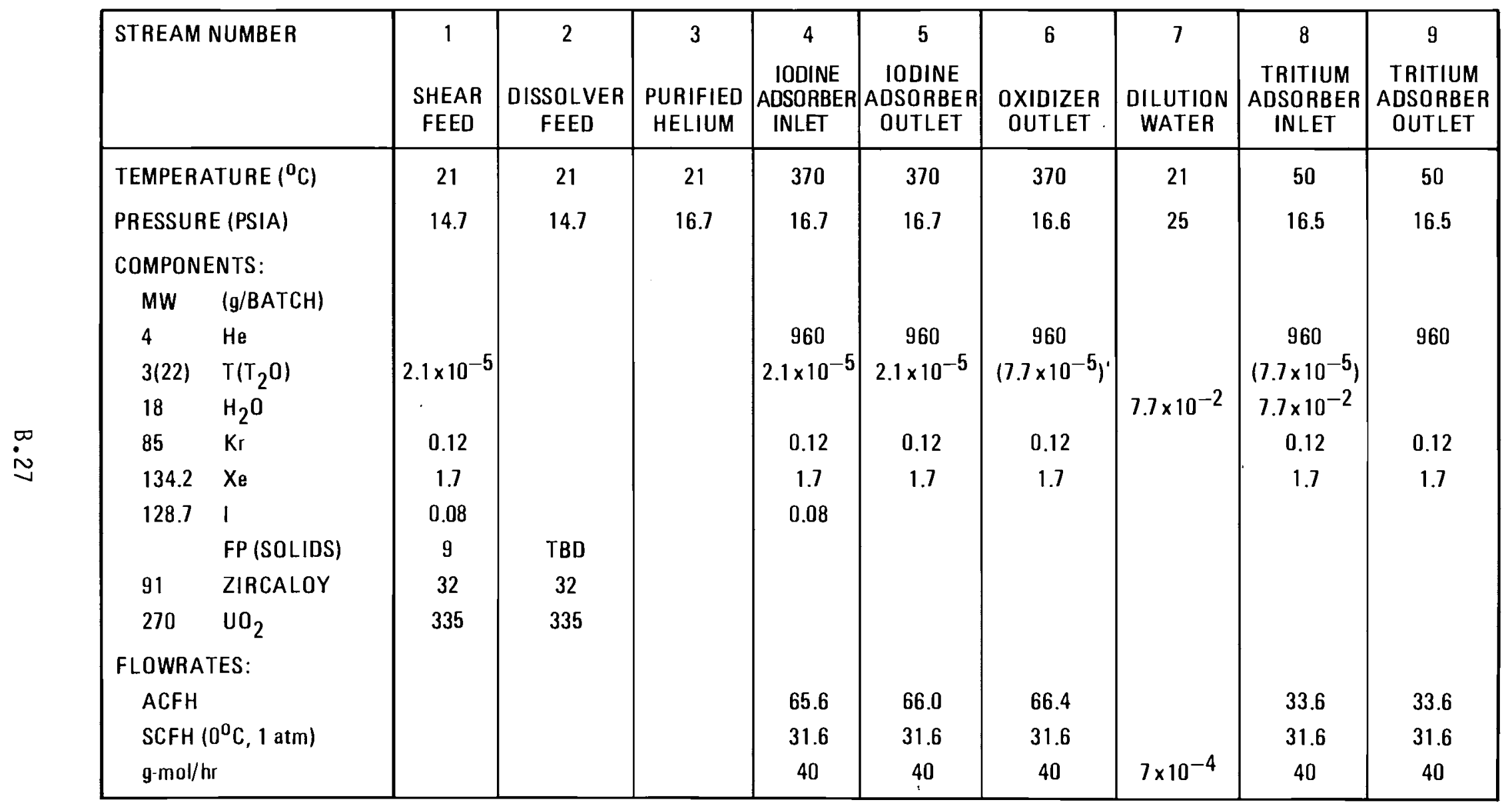


The iodine adsorber is a 3/4-in. SCH 40s pipe, $1 \mathrm{ft}$ in length. The adsorber is packed with $50 \mathrm{~g}$ of alkali-metal-impregnated charcoal.

The oxidizer module is a 1-1/2-in. SCH 40s pipe, $1 \mathrm{ft}$ in length. The oxidizer is packed with $40 \mathrm{~g}$ of $1 / 8-\mathrm{in}$. high-activity alumina extrudate containing 10 wt\% copper oxide.

The precooler is a 1-1 single-pass, shell and tube heat exchanger. Contaminated helium passes through the tube side, and water passes through the shell side. A heat transfer surface area of $25 \mathrm{ft}^{2}$ is required. The tritiated water adsorber is a 1-1/2-in. SCH 40s pipe, $1 \mathrm{ft}$ in length. This adsorber is packed with $75 \mathrm{~g}$ of $5 \AA$ molecular sieve material.

All process piping is $1 / 2-i n$. stainless-steel tubing. 
TECHNICAL ASSESSMENT

Based on current information, both voloxidation and thermal outgassing appear capable of significantly reducing the tritium content of irradiated LWR fuels prior to dissolution operations. Thermal outgassing has the following major process advantages:

1. The high-temperature furnace is easy to operate and control, has no rotating parts, is remotely serviceable, and requires no additional engineering development costs.

2. The off-gas treatment system is similar in design to a proven helium purification system for a high-temperature gas-cooled reactor (HTGR).

3. The process is compatible with other fuel types, including thorium-based fuels.

4. The direct costs are competitive with voloxidation.

5. The off-gas treatment system is the least affected by increased throughput. In fact, higher concentrations of ${ }^{3} \mathrm{H}$, etc. will result in higher DFs.

6. In general, higher throughput does not affect the overall technical feasibility in terms of process equipment.

The thermal outgassing process has the following disadvantages:

1. Semivolatile fission products have increased mobility.

2. The Zircaloy cladding can become embrittled and subsequently impact dissolver operations.

3. Few materials can withstand temperatures as high as $1500^{\circ} \mathrm{C}$. Further laboratory-scale thermal outgassing tests are recommended to support the design assumptions made here. The removal efficiency of tritium from clad fuel segments remains to be verified, and the volatility of heavy-metal fission products, especially cesium, needs to be determined in order to 
estimate the necessary shielding requirements throughout the process. Also, the decontamination factors for the various adsorber columns need to be verified.

A high temperature furnace(s) can be manufactured and operated relative to a large-scale 5 metric tons/day process. However, more detailed design is recommended. Criticality concerns, remote maintainability, floorspace, fuel charging and unloading mechanisms, etc. need further evaluation. 


\section{ACKNOWLEDGMENTS}

The authors thank C. A. Perry, S. Strausberg, and A. J. Kennedy for their helpful assistance regarding the Fort St. Vrain helium purification system. 


\section{REFERENCES}

Anderson, H. F., and C. J. Kershner. 1977. Tritium Waste Control Project, Project Report, July-September, 1976. MLM-2399, Monsanto Research Corporation, Miamisburg, Ohio.

Bebbington, W. P., and V. R. Thayer. 1959. "Production of Heavy Water." Chem. Eng. Progr. 55(9):70-78.

Bixel, J. C., B. W. Hartzell, and W. K. Park. 1976. "Experimental Determination of Reactor Rates of Water: Hydrogen Exchange of Tritium with Hydrophobic Catalyst." In Proceedings of the 14th ERDA Air Cleaning Conference, pp. 1065-1075, M. W. First (ed.), Harvard University, Boston (CONF-760822P2).

Campbel1, D. 0., and W. L. Pattison. 1981. The Effect of Heat Treatments on Tritium Volatility and the Behavior of Other Radioactive Constituents in Irradiated Fuel. ORNL-TM-7326, Oak Ridge National Laboratory, Oak Ridge, Tennessee.

Goode, J. H., et al. 1980. Head-End Reprocessing Studies of H. B. Robininson2 Fuel. II. Parametric VoToxidation Studies. ORNL-TM-6888, V. II, Oak Ridge National Laboratory, Oak Ridge, Tennessee.

Goode, J. H., et al. 1978. Head-End Reprocessing Studies with H. B. Robinson2 Fuel. ORNL-TM-6037, Oak Ridge National Laboratory, Oak Ridge, Tennessee.

Goode, J. H., et al. 1973. Voloxidation: Removal of Volatile Fission Products from Spent LMFBR Fuels. ORNL-TM-3723, Oak Ridge National Laboratory, Oak Ridge, Tennessee.

Grimes, W. R., et al. 1982. An Evaluation of Retention and Disposal Options for Tritium in Fuel Reprocessing. ORNL-TM-8261, Oak Ridge National Laboratory, Oak Ridge, Tennessee.

Hall, N. E., and G. N. Ward. 1975. Tritium Control by Water Recycle in a Nuclear Fuel Reprocessing Plant. NEDG-11342, General Electric Company, San Jose, California.

Kullen, B. J., L. E. Trevorrow, and M. J. Steindler. 1975. Tritium and NobleGas Fission Products in the Nuclear Fuel Cycle. II. Fuel Reprocessing Plants. ANL-8135, V. II, Argonne National Laboratory, Argonne, Illinois.

Lin, K. H. 1972. Tritium Enrichment by Isotope Separation Technique. ORNLTM-3976, Oak Ridge National Laboratory, Oak Ridge, Tennessee.

Murbach, E. W., et al. 1974. Fission Product Gas Retention Process and Equipment Design Study. ORNL-TM-4560, Oak Ridge National Laboratory, Oak Ridge, Tennessee. 


\section{REFERENCES (Contd)}

ORNL. 1981. Conceptual Design Report, Hot Experimental Facility, Oak Ridge, Tennessee. ORNL/CFRP-81/4, V. III, Oak Ridge, Tennessee.

ORNL. 1978. Advanced Fuel Recycle Program Progress Report for Period January 1 to March 31, 1978. ORNL-TM-6306, Oak Ridge, Tennessee.

ORNL. 1970. Siting of Fuel Reprocessing Plants and Waste Management Facilities. ORNL-4451, Oak Ridge, Tennessee. 


\section{DISTRIBUTION}

No. of

Copies

\section{OFFSITE}

27 DOE Technical Information Center

R. E. Cunningham

Office of Nuclear Safety

Materials and Safeguards

Room 562

Nuclear Regulatory Commission

7915 Eastern Avenue

Silver Springs, MD 20910

3 Division of Waste Management

Nuclear Regulatory Commission Washington, DC 20555

ATTN: J. B. Martin

D. B. Rohrer

R. D. Smith

Materials Section Leader

High Level Waste Licensing Branch

Nuclear Regulatory Commission

Washington, D. C. 20555

W. E. Mott

DOE Division of Environmental Control Technology

EV-13, GTN

Washington, D. C. 20545

3 DOE- Uffice of Terminal Waste

Disposal and Remedial Actions

NE30, GTN

Washington, D. C. 20545

Attn: F. E. Coffman

J. R. Coleman

J. A. Turi
No. of

Copies

4 DOE Office of Spent Fuel

Management and Reprocessing Systems

Washington, D. C. 20545

Attn: N.W. Ballard

C. B. Bastin

K. 0. Laughon

W. H. McVey

3 DOE Office of Defense Waste and Byproducts Management

DP-12, GTN

Washington, DC 20545

ATTN: T. C. Chee

G. Oertel

R. D. Walton

2 Geologic Repository Division

Nuclear Waste Policy Act

Project Office: DOE

S-10 Forrestal Bldg.

Washington, DC 20585

ATTN: J. W. Bennett

M. J. Lawrence

C. R. Cooley

Geologic Repository Division

Nuclear Waste Policy Act

S-10/NE-22 GTN

Washington, D. C. 20585

Environmental Protection Agency

Technological Assessment Division (AW-559)

Office of Radiation Programs

Washington, DC 20460 
No. of

Copies

S. A. Mann

DOE Chicago Operations and

Region Office

Aryonne, IL 60439

J. 0. Neff

DOE Columbus Program Office

505 King Avenue

Columbus, $\mathrm{OH} 43201$

3 DOE Idaho Operations Office

550 Second Street

Idaho Falls, ID 83401

Attn: J.P. Hamric

J. B. Whitsett

M. A. Widmayer

Office of the Assistant Manager

for Energy Research and

Development

DOE Oak Ridge Operations Office

P. 0. Box E

Oak Ridge, TN 37830

3 DOE Savannah River Laboratory

P.0. Box A

Aiken, SC 29801

ATTN: E. S. Goldberg

T. B. Hindman

R. B. Whitfield

R. Y. Lowrey

DOE Albuquerque Operations Office

P. 0. Box 5400

Albuquerque, NM 87185

S. G. Harbinson

DOE San Francisco Operations Office

1333 Broadway

0akland, CA 94612

W. F. Holcomb

National Institute of Health

Radiation Safety Branch

Building 21

Bethesda, MD 20205
No. of

Copies

2 Allied-General Nuclear Services

P. 0. Box 847

Barnwel1, SC 29812

ATTN: J. A. Buckham

A. Williams

2 Argonne National Laboratory

9700 South Cass Avenue

Argonne, IL 60439

ATTN: J. H. Kittel

M. J. Steindler/

L. E. Trevorrow

9 Battelle Memorial Institute

505 King Avenue

Columbus, $\mathrm{OH} 43201$

ATTN: S. H. Basham

A. Carbiener

N. E. Carter-

J. 0. Duguid

S. Goldsmith

P. L. Hofmann

M. Kehnemuyi

J. F. Kircher

B. Rawles

2 EG\&G Idaho, Inc.

P. 0. Box 1625

Idaho Fal1s, ID 83415

ATTN: G. B. Levin

R. L. Tallman

R. Williams

Electric Power Research Institute $3412 \mathrm{Hillview}$ Avenue

P. 0. Box 10412

Palo Alto, CA 94304

3 Exxon Nuclear Idaho

P. 0. Box 2800

Idaho Falls, ID 83401

ATTN: R. A. Brown

J. D. Christian

T. R. Thomas 
No. of

Copies

6 Oak Ridge National Laboratory P.0. Box $X$

Oak Ridge, TN 37830

ATTN: J. 0. Blomeke

W. D. Burch

A. G. Croff

R. J. Jubin

R. G. Wymer

T. H. Row

7 E. I. duPont deNemours \& Co. Inc. Savannah River Laboratory

Aiken, SC 29801

ATTN: H. H. Baker

M. D. Boersma

J. L. Crandall

S. D. Harris

D. L. McIntosh

S. Mirshak

S. W. O'Rear

E. Vejvoda

Rockwell International

Rocky Flats Plant

P. 0. Box 464

Golden, CO 80401

4 GA Technologies

P. 0. Box 81608

San Diego, CA 92138

ATTN: G. E. Benedict

W. S. Scheib, Jr.

L.J. 01 guin

R. D. Wilbourn

J. L. Larocca, Chairman

Energy Research and Development Authority

Empire State Plaza

Albany, NY 12223

2 Lawrence Livermore Laboratory

P. 0. Box 808

Livermore, CA 94550

ATTN: J.H. Campbell

W. G. Sutliff
No. of

Copies

3 Sandia Laboratories

Albuquerque, NM 87185

Attn: 0. E. Jones

R. G. Kepler

W. Weart

R. Roy

202 Materials Research Laboratory

University Park, PA 16802

J. R. Potter

Chem-Nuclear Systems, Inc.

P. 0. Box 1866

Bellevue, WA 98009

R. G. Post

College of Engineering

University of Arizona

Tucson, AZ 85721

W. A. Freeby

Bechtel Group, Inc.

Fifty Beale Street

P. 0. Box 3965

San Francisco, CA 94119

L. L. Hench

Dept. of Materials Science and Engineering

University of Florida

Gainesville, FL 32611

H. Palmour II I

2140 Burlington Engineering Laboratories

North Carolina State University

Raleigh, NC 27607

W. Tope

Westinghouse Electric Corporation Penn Center, Building 2

Box 355

Pittsburgh, PA 15230 
No. of

Copies

ONSITE

4 DOE Richland Operations Office

P. F. X. Dunigan, Jr.

H. E. Ranson

J. J. Schreiber (2)

13 Rockwell Hanford Dperations

J. L. Deichman

J. 0. Honeyman

L. Jensen

J. E. Kinser

H. G. McGuire

R. M. Orme

J. Reser

J. H. Roecker

W. W. Schulz

R. E. Van der Cook

D. G. Wilkins

G. D. Wright

File Copy

2 UNC United Nuclear Industries

F. H. Bouse, Document Control

T. E. Dabrowski

4 Westinghouse Hanford Company

D. L. Baldwin

C. A. Hinman

R. E. Lerch

J. J. McCown
No. of

Copies

68 Pacific Northwest Laboratory

W. F. Bonner

F. P. Brauer

L. A. Bray (15)

L. L. Burger (15)

T. D. Chikalla

C. R. Hann

0. F. Hill

J. H. Jarrett

A. B. Johnson, Jr.

S. E. King

M. R. Kreiter

L. T. Lakey

R. C. Liikala

R. P. Marshall

E. D. MCClanahan

J. L. MCE Iroy

J. E. Mendel

L. G. Morgan

I. C. Nelson

J. M. Nielsen/R. W. Perkins

R. E. Nightingale

A. M. Platt

W. A. Ross

J. M. Rus in

R. D. Scheele

J. K. Soldat

J. L. Swanson

G. L. Tingey

C. L. Unruh

H. H. Van Tuyl

E. C. Watson

E. J. Wheelwright

W. R. Wiley

Technical Information (5)

Publishing Coordination (2) 